\title{
Two-Stage Origin of K-Enrichment in Ultrapotassic Magmatism Simulated by Melting of Experimentally Metasomatized Mantle
}

\author{
Michael W. Förster ${ }^{1, *}$, Stephan Buhre ${ }^{2}$, Bo $\mathrm{Xu}^{1,3}{ }^{1}$, Dejan Prelević ${ }^{2,4}{ }^{\circ}$, Regina Mertz-Kraus ${ }^{2}$ and \\ Stephen F. Foley ${ }^{1} \mathbb{D}$ \\ 1 ARC Centre of Excellence of Core to Crust Fluid Systems and Department of Earth and Planetary Sciences, \\ Macquarie University, NSW 2109, Australia; xubo@outlook.com.cn (B.X.); stephen.foley@mq.edu.au (S.F.F.) \\ 2 Institute für Geowissenschaften, Johannes Gutenberg Universität, 55099 Mainz, Germany; \\ buhre@uni-mainz.de (S.B.); prelevic@uni-mainz.de (D.P.); mertzre@uni-mainz.de (R.M.-K.) \\ 3 State Key Laboratory of Geological Processes and Mineral Resources, China University of Geosciences, \\ Beijing 10083, China \\ 4 Faculty of Mining and Geology, University Belgrade, Đušina 7, 11000 Belgrade, Serbia \\ * Correspondence: michael.forster@mq.edu.au
}

Received: 17 November 2019; Accepted: 27 December 2019; Published: 31 December 2019

\begin{abstract}
The generation of strongly potassic melts in the mantle requires the presence of phlogopite in the melting assemblage, while isotopic and trace element analyses of ultrapotassic rocks frequently indicate the involvement of subducted crustal lithologies in the source. However, phlogopite-free experiments that focus on melting of sedimentary rocks and subsequent hybridization with mantle rocks at pressures of 1-3 GPa have not successfully produced melts with $\mathrm{K}_{2} \mathrm{O}>5 \mathrm{wt} \%-6 \mathrm{wt} \%$, while ultrapotassic igneous rocks reach up to $12 \mathrm{wt} \% \mathrm{~K}_{2} \mathrm{O}$. Accordingly, a two-stage process that enriches $\mathrm{K}_{2} \mathrm{O}$ and increases $\mathrm{K} / \mathrm{Na}$ in intermediary assemblages in the source prior to ultrapotassic magmatism seems likely. Here, we simulate this two-stage formation of ultrapotassic magmas using an experimental approach that involves re-melting of parts of an experimental product in a second experiment. In the first stage, reaction experiments containing layered sediment and dunite produced a modally metasomatized reaction zone at the border of a depleted peridotite. For the second-stage experiment, the metasomatized dunite was separated from the residue of the sedimentary rock and transferred to a smaller capsule, and melts were produced with $8 \mathrm{wt} \%-8.5 \mathrm{wt} \% \mathrm{~K}_{2} \mathrm{O}$ and $\mathrm{K} / \mathrm{Na}$ of 6-7. This is the first time that extremely K-enriched ultrapotassic melts have been generated experimentally from sediments at low pressure applicable to a post-collisional setting.
\end{abstract}

Keywords: lamproites; high-pressure experiments; ultrapotassic; K-enrichment; subduction zones

\section{Introduction}

"Alkaline igneous rocks" is an umbrella term describing all igneous rocks that are generally enriched in the oxide species $\mathrm{Na}_{2} \mathrm{O}$ and $\mathrm{K}_{2} \mathrm{O}$ relative to sub-alkaline (tholeiitic) rocks at similar $\mathrm{SiO}_{2}$ [1]. The alkaline rocks include sodic and potassic series, depending on the dominant oxide species. Potassic rocks are defined as comprising $\mathrm{K}_{2} \mathrm{O}>\mathrm{Na}_{2} \mathrm{O}$ in $w \mathrm{t} \%$ and include compositional ranges from leucite-bearing basanites to K-enriched rock variants like leucitites, lamprophyres, orangeites, shoshonites, and lamproites [2]. Ultrapotassic (UP) lavas are alkaline igneous rocks with $>3 \mathrm{wt} \%$ of both $\mathrm{K}_{2} \mathrm{O}$ and $\mathrm{MgO}$, in which $\mathrm{K}_{2} \mathrm{O} / \mathrm{Na}_{2} \mathrm{O}$ ratios exceed 2 [3]. They also show extreme trace element and isotopic enrichment. Potassium-rich magmatism is a common feature in the post-collisional stage of orogenic belts and exhibits compositions ranging from basic to silica-rich. Direct melting of the primitive mantle, which has a K/Na of $\sim 0.1$ [4], and thus contains ca. 10 times less $\mathrm{K}_{2} \mathrm{O}$ than $\mathrm{Na}_{2} \mathrm{O}$, 
cannot produce potassic alkaline magmas with $\mathrm{K}_{2} \mathrm{O}>\mathrm{Na}_{2} \mathrm{O}$ [5]. Instead, $\mathrm{K}_{2} \mathrm{O}$ has to be enriched at source, and the isotopic compositions of most potassic alkaline magmas probably lie within the metasomatically overprinted lithospheric mantle.

Two models try to explain the enrichment of $\mathrm{K}_{2} \mathrm{O}$ and $\mathrm{K} / \mathrm{Na}$ within Earth's mantle: (A) a two-stage metasome "vein + wall rock" melting model [6], and (B) a single-stage recycled sediment/crust melting model (e.g., [7]).

(A) The metasome melting model is a two-stage model that proposes that the UP magmas are produced by melting of a modally metasomatized mantle source that has been enriched in phlogopite and pyroxene in a first stage [8-11]. These phlogopite-rich "metasomes" may be pyroxenites or glimmerites, most likely formed when K-rich liquids react with peridotite to form layers and veins [12-14]. Experimental studies have successfully produced melts of UP composition from phlogopite-bearing and phlogopite-veined peridotites [15-18]. This explanation often does not specify the ultimate origin of the glimmeritic metasomes or the K-rich liquids that generated them.

(B) In contrast with the above model, other studies propose direct melting of subducted sediments [19] and/or continental crustal material [20], which mix with peridotite to form mélanges that melt to form UP magmas [7] in a single stage. Subducted crustal rocks have generally low solidus temperatures of $>675{ }^{\circ} \mathrm{C}$, which strongly depend on pressure and volatile contents [20-22]. Therefore, when the felsic crustal material is buried to mantle depths, it will preferentially melt and react with surrounding peridotite. As continental lithologies are usually K-rich compared with mantle rocks (K/Na 1-2), they can provide the K-enrichment for the potassic-ultrapotassic melts [23,24]. The concept of single-stage formation of UP lavas from recycled crustal components is grounded in the isotopic and geochemical compositions of post-collisional lavas, which are enriched in ${ }^{87} \mathrm{Sr} /{ }^{86} \mathrm{Sr}$ and show trace element patterns that are similar to the average composition of globally subducted sediment (GLOSS) [25]. Other studies have suggested other recycled crustal components, including blueschists [26], terrigenous siliciclastic sediments [9], and marly sediments [27].

However, recycled crustal components do not necessarily have to melt directly to produce UP melts in a single stage, but may produce an intermediate pyroxenitic component as in model (A). This is evident from olivines within post-collisional lavas that exhibit extreme Fo (94) and $\mathrm{NiO}>0.5 \mathrm{wt} \%$, which indicate a role for ultra-depleted peridotites [12,28]. To account for the crust-like geochemical composition of the post-collisional lavas, these pyroxenites must be phlogopite-rich and characterized by high ${ }^{87} \mathrm{Sr} /{ }^{86} \mathrm{Sr}$ isotopic and sediment-like trace element compositions. Given the widespread occurrence of post-collisional lavas, there also has to be a commonly occurring mechanism that produces pyroxenites with crust-like isotopic and trace element compositions within the lithospheric mantle. Furthermore, experiments on sediment and peridotite hybridization at pressures of 1-3 GPa, which are equivalent to depths of the sources of post-collisional ultrapotassic rocks [28,29], produce melts that are restricted to $<6 \mathrm{wt} \% \mathrm{~K}_{2} \mathrm{O}$ on average $[30,31]$, and indicate the importance of phlogopite pyroxenites as an intermediate product in the generation of UP melts. These phlogopite pyroxenites may not melt immediately following their formation and may reside within the lithospheric for several hundreds of millions of years before they are activated by lithospheric heating and re-juvenation.

In this study, we simulate the metasome melting model (A) for the formation of UP melts using a two-stage experimental approach in which parts of an experimental product are re-used in a second experiment (e.g., [32]). The two experimental stages are (1) heating of two-layer charges consisting of carbonate-bearing siliciclastic marine sediment and dunite, resulting in a phlogopite-rich pyroxenite metasomatic reaction layer; and (2) partial melting of the phlogopite-rich pyroxenite synthesized in the first experiment to generate UP melts with $\mathrm{K}_{2} \mathrm{O}>6 \mathrm{wt} \%$.

\section{Experimental Strategy}

The two-stage experimental approach directly simulates the formation of UP magmas from a mantle metasomatized by melts of sediments. The use of natural materials enables us to compare trace element patterns of experimental melts with those found in natural K-rich lavas. The two-stage 
approach also provides realistic mineral assemblages as starting material for the second stage melting experiments. The two-stage hypothesis is based on the following observations:

1. An increasing number of studies imply that fore-arc regions of long-lived volcanic arcs with abundant calk-alkaline volcanism may act as an important host for phlogopite-rich pyroxenites [33,34]. Trenchward migration of volcanism leads to extreme potassium and trace element enrichment in the erupted lavas, indicating that the fore-arc mantle is strongly metasomatized. Enrichment of the fore-arc probably takes place during subduction of sediments that melt at temperatures as low as $675^{\circ} \mathrm{C}$ to produce Si-rich melts $[21,22]$. These Si-rich melts rise from the slab surface and immediately react with peridotite to produce phlogopite pyroxenites $[23,35,36]$. As phlogopite pyroxenites, as well as phlogopite peridotites, have solidi of $\sim 1100-1200^{\circ} \mathrm{C}[15,16,37,38]$, far above the melting temperatures of sedimentary rocks, the cold (as low as $675^{\circ} \mathrm{C}$ ) sediment melts within the fore-arc are completely consumed in this process.

2. Mantle xenoliths from arcs [39] as well as from various locations within the lithospheric mantle (e.g., [40-42]) demonstrate the presence of phlogopite enriched metasomes.

3. Trace element and isotope compositions of post-collisional volcanic rocks indicate thorough mixing of recycled crustal components in the source region (e.g., [43]).

4. Trace element signatures of olivine phenocrysts indicate the presence of pyroxenite in the source [12,29].

5. UP lavas have to be produced by the reaction of a melt of a low solidus vein and wall-rock peridotite with higher solidus, because multiple saturation points including $\mathrm{Ol}$, Opx, $\mathrm{Cpx}$, and $\mathrm{Gt} / \mathrm{Sp}$ on various fluid contents and species as well as oxygen fugacities are absent under any conditions in liquidus experiments [13].

6. Direct melting of sediments and hybridization with peridotite at $<3 \mathrm{GPa}$ cannot generate melts with $\mathrm{K}_{2} \mathrm{O}$ mass fractions exceeding $6 \mathrm{wt} \%$ on average (e.g., [31]).

7. UP magmatism shows a prolonged activity of tens of millions of years' duration within a given region, indicating that the recycled component is able to reside for a long time within the mantle lithosphere (e.g., $[44,45])$.

\section{Materials and Methods}

\subsection{Starting Materials}

The sedimentary starting material was acquired from the International Ocean Discovery Project (IODP) site ODP 161-976 B 18 X3 105-106.5 (Supplementary Data Table S2) and is a hydrous, carbonate-bearing, siliciclastic marine sediment with $<10 \%$ carbonate. This sample was selected to determine how local Mediterranean sediment is involved in the formation of UP lavas in the same region. Three aliquots of the sediment were analyzed for $\mathrm{H}(1.83 \mathrm{wt} \%), \mathrm{C}(8.18 \mathrm{wt} \%)$, and $\mathrm{N}(0.35 \mathrm{wt} \%)$ in an automated vario EL cube elemental analyzer (Elementar, Langenselbold, Germany) [46].

A dunite (sample ZD11-53) from the Zedang ophiolite (south Tibet, China) containing olivine $(>97 \%)$, spinel $(\sim 2 \%)$, and clinopyroxene $(<1 \%)$ was used as the depleted peridotite (Supplementary Data Table S2). Both samples were powdered in an agate mortar.

\subsection{Experimental and Analytical Techniques}

Experiments were carried out using a piston cylinder apparatus at the University of Mainz, which produces exceptionally well-preserved glasses owing to rapid quench rates realized by extra cooling channels through the bomb plate close to the WC cores [47]. For the first-stage experiments (3 GPa and $800-1000{ }^{\circ} \mathrm{C}$ ), the dunite was placed as a distinct layer on top of the sediment in a 30/70 ratio and sealed in $4 \mathrm{~mm}$ diameter capsules. Starting materials were filled into carbon capsules, where $\mathrm{fO}_{2}$ lies below the $\mathrm{C}+\mathrm{CO}+\mathrm{CO}_{2}$ equilibrium, and these were placed into sealed platinum capsules. The assemblies consisted of $\mathrm{Al}_{2} \mathrm{O}_{3}$ spacers, a graphite furnace, $\mathrm{B}$-type thermocouple, and a sintered $\mathrm{CaF}_{2}$ outer spacer. Thermobaric conditions correspond to the fore-arc setting of a subduction zone [48]. All 
assemblies were pressurized first and heated at a rate of $50{ }^{\circ} \mathrm{C} / \mathrm{min}$. Pressure and temperature were kept constant for 1-14 days. All charges were quenched to temperatures below $500{ }^{\circ} \mathrm{C}$ within $8 \mathrm{~s}$ [47]. After the experiments, capsules were cut in half longitudinally; one half was embedded in epoxy and polished for characterization of the charges, and the other half was prepared for the second-stage melting experiment.

For the second-stage melting experiment, the completed first-stage experiment was dissected with a scalpel to separate the metasomatized dunite from the reacted sediment. The experiment at $900{ }^{\circ} \mathrm{C}$ was used for this purpose because the dunite contained the thickest phlogopite layer. The size of the cut out is highlighted by the blue box in Figure 1. During this mechanical extraction process, the sample material disintegrated into smaller pieces, which were sealed together in a capsule measuring $2 \mathrm{~mm}$ in diameter.

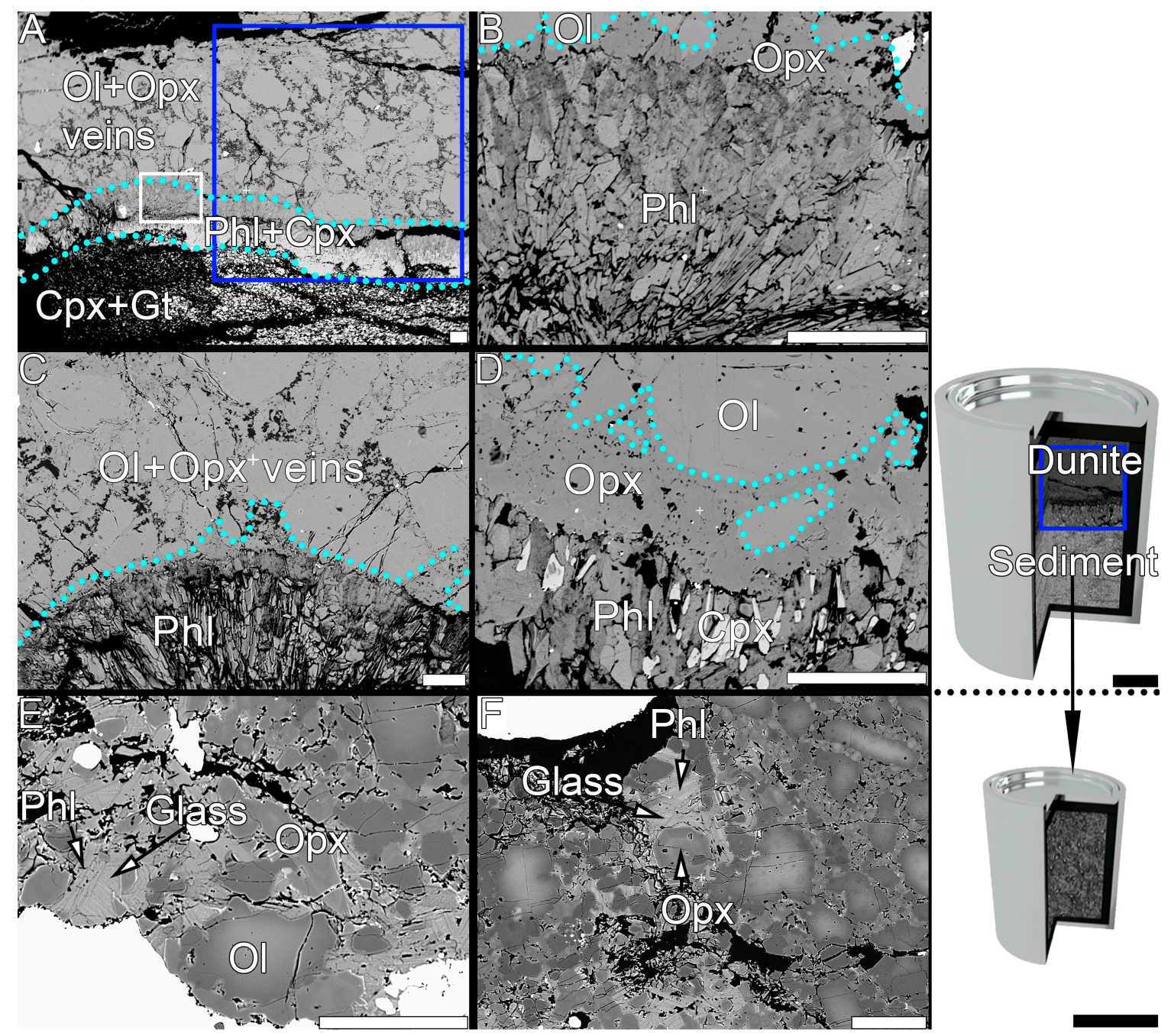

Figure 1. Backscattered electron images of reaction zones in high-pressure experiments. (A) Reaction experiment at $3 \mathrm{GPa} / 900{ }^{\circ} \mathrm{C}$ with dunite upper layer and sediment lower layer. Light blue dotted line highlights the extent of a 300-400 $\mu \mathrm{m}$ thick reaction zone composed of phlogopite and clinopyroxene. Blue square indicates the portion extracted for the second-stage experiment. (B-D) Close-ups of the upper part of the reaction zone (blue box in A). (E,F) Second-stage experiment in which the metasomatized dunite (blue square: reaction zone and dunite) of the experiment in (A) was melted at 2 $\mathrm{GPa} / 1200{ }^{\circ} \mathrm{C}$. All white scale bars (A-F) are $100 \mu \mathrm{m}$, while black scale bars for both capsules are $1 \mathrm{~mm}$.

Major element contents of experimental run products were acquired using a JEOL JXA 8200 superprobe electron-probe microanalyzer (EPMA) equipped with five wavelength dispersive 
spectrometers at the University of Mainz, Germany. All samples were measured using $15 \mathrm{kV}$ accelerating voltage, spot sizes of $2 \mu \mathrm{m}$ for silicate phases and $10 \mu \mathrm{m}$ for glass phases, and a beam current of $12 \mathrm{nA}$ with peak counting times of 20-30 s. A range of synthetic materials were used as reference materials. Analyses are presented in Supplementary Data Tables S1-S10.

Trace element mass fractions (Supplementary Data Tables S11-S14) were determined using laser ablation-inductively coupled plasma mass spectrometry (LA-ICP-MS) at the University of Mainz and solution ICP-MS at Macquarie University, Sydney.

Glass and mica from the $3 \mathrm{GPa} / 1000{ }^{\circ} \mathrm{C}$ experiment were ablated using an ESI NWR193 ArF Excimer laser ablation system (193 nm wavelength) equipped with a TwoVol2 ablation cell. The ablation rate was set to $10 \mathrm{~Hz}$ at $3 \mathrm{~J} / \mathrm{cm}^{2}$. The dry aerosol was transferred to an Agilent 7500ce mass spectrometer by a He-Ar mixed gas flow. Background signals were acquired for $20 \mathrm{~s}$, followed by a dwell time of $30 \mathrm{~s}$ with spot sizes of $20 \mu \mathrm{m}$ at each analyzed spot. For calibration, synthetic NIST SRM 612 was used with published values [49] and ${ }^{29} \mathrm{Si}$ was selected as the internal standard using the $\mathrm{SiO}_{2}$ mass fractions determined by EPMA. USGS BCR-2G was analyzed as an unknown in each run for quality control; measured values were within 10\% of the data tabulated in the GeoReM database [50]. Data processing and reduction were carried out using the commercial software GLITTER 4.4.1 [51]. Trace-element mass fractions in the sediment were measured by solution ICP-MS. For quality control, USGS BHVO-1 and BIR-1 were measured as unknowns and values are within $10 \%$ of the data tabulated in the GeoReM database [50].

\section{Results}

\subsection{First-Stage Experiments}

Four first-stage reaction experiments were performed at $3 \mathrm{GPa}$ at temperatures ranging from 800 to $1000{ }^{\circ} \mathrm{C}$ (Table 1). The breakdown of carbonate, clay, and organic material produces a mixed $\mathrm{H}_{2} \mathrm{O}$ $\pm \mathrm{H}_{2} \pm \mathrm{CO}_{2} \pm \mathrm{CO} \pm \mathrm{CH}_{4}$ fluid, whose speciation strongly depends on pressure, temperature, and oxygen fugacity. Given carbon saturation, the decomposition of the sediment follows the following reaction: $\mathrm{CH}_{4}+\mathrm{H}_{2} \mathrm{O}=3 \mathrm{H}_{2}+\mathrm{CO}$ [52].

The sedimentary starting material contained $2.57 \mathrm{wt} \% \mathrm{~K}_{2} \mathrm{O}$ with a $\mathrm{K} / \mathrm{Na}$ ratio of 1.85 (Supplementary Data Table $\left.\mathrm{S} 2, \mathrm{~K}_{2} \mathrm{O} / \mathrm{Na}_{2} \mathrm{O}=1.65\right)$. All experiments show a reaction zone $(80-400 \mu \mathrm{m})$ sandwiched between the sediment and dunite layers, which consists of a phlogopite and clinopyroxene corona on the sediment side as well as massive orthopyroxene on the dunite side of the reaction zone (Figure $1 \mathrm{~A}-\mathrm{D})$. This reaction zone contains mainly phlogopite ( $\sim 40 \mathrm{vol} \%-80 \mathrm{vol} \%)$ and clinopyroxene ( $20 \mathrm{vol} \%-50 \mathrm{vol} \%)$, as well as minor amounts of orthopyroxene ( $<10 \mathrm{vol} \%)$ and garnet $(<5 \mathrm{vol} \%)$, while accessory minerals include apatite and Fe-Ni-sulphides. Experiments at 800, 850, and $900{ }^{\circ} \mathrm{C}$ also contain veins of orthopyroxene with minor amounts of magnesite extending into the dunite layer from the reaction zone along olivine grain boundaries. The former sedimentary rock fraction contains 15 vol\%-22 vol\% Mn-rich garnet (gr 0.31 alm 0.27 pyr 0.22 sp 0.19), 20 vol\%-50 vol\% Na-Al-rich clinopyroxene (di $0.66 \mathrm{jd} 0.34$ ), 20 vol\%-40 vol\% and glass in all experiments, while phengite at 850 ${ }^{\circ} \mathrm{C}$ and coesite at $800{ }^{\circ} \mathrm{C}$ were also found [53] (Tables 2 and 3). All first-stage reaction experiments produced hydrous silica-rich glasses, which were the result of $20 \%-40 \%$ melting of the sediment (Table 2, Supplementary Data Table S8), ranging from $70 \mathrm{wt} \%-79 \mathrm{wt} \% \mathrm{SiO}_{2}$ (Figures $2 \mathrm{~A}$ and $3 \mathrm{~A}$ ) at $800-900{ }^{\circ} \mathrm{C}$ to $53 \mathrm{wt} \%-58 \mathrm{wt} \% \mathrm{SiO}_{2}$ at $1000{ }^{\circ} \mathrm{C}$, when recalculated to a $100 \mathrm{wt} \%$ anhydrous composition. All glasses have $<6 \mathrm{wt} \% \mathrm{~K}_{2} \mathrm{O},<16 \mathrm{wt} \% \mathrm{Al}_{2} \mathrm{O}_{3},<4 \mathrm{wt} \% \mathrm{CaO}$, and $<2 \mathrm{wt} \% \mathrm{Na}_{2} \mathrm{O}$ (Figure 3A-D), while $\mathrm{K} / \mathrm{Na}$ ranges from 2.8 to 6.4 (Figure $4 \mathrm{~A}$ ). Clinopyroxene shows a continuous range of compositions across the reaction zone with increasing $\mathrm{Na}_{2} \mathrm{O}(0.6 \mathrm{wt} \%-4 \mathrm{wt} \%)$ and $\mathrm{Al}_{2} \mathrm{O}_{3}(2 \mathrm{wt} \%-10 \mathrm{wt} \%)$ towards the sediment, while $\mathrm{Na}_{2} \mathrm{O}$ decreases with temperature from $3 \mathrm{wt} \%$ to $1 \mathrm{wt} \%$ (Figure $2 \mathrm{~B}$ ). 
Table 1. Melting phase relations of reaction experiments and second-stage melting experiment.

\begin{tabular}{|c|c|c|c|c|c|c|c|c|}
\hline$\#$ & Composition & $\mathrm{T}\left({ }^{\circ} \mathrm{C}\right)$ & $\begin{array}{c}\mathbf{P} \\
(\mathrm{GPa})\end{array}$ & Melt (\%) & Phases in Sediment Layer & Reaction Zone Phases & $\begin{array}{c}\text { Phases in } \\
\text { Dunite }\end{array}$ & Duration \\
\hline 1 & Sediment/Dunite reaction & 800 & 3 & $\sim 10$ & $\begin{array}{c}\mathrm{Gt}+\mathrm{Cpx}+\mathrm{Phe}+\mathrm{Ap}+\mathrm{Cc}+ \\
\text { Coe }+ \text { Si-rich melt }\end{array}$ & $\mathrm{Cpx}+\mathrm{Phl}+\mathrm{Opx}$ & $\mathrm{Ol}+\mathrm{Opx}+\mathrm{Mgs}$ & $7 \mathrm{~d}$ \\
\hline 2 & Sediment/Dunite reaction & 850 & 3 & $\sim 20$ & $\begin{array}{c}\mathrm{Gt}+\underset{\text { Si-rich melt }}{\mathrm{Cpx}}+\mathrm{Phe}+\mathrm{Ap}+ \\
-\end{array}$ & $\begin{array}{c}\mathrm{Phl}+\mathrm{CPx}+\mathrm{Opx}+\mathrm{Ap}+ \\
\text { Fe-Ni Sulphides }\end{array}$ & $\mathrm{Ol}+\mathrm{Opx}+\mathrm{Mgs}$ & $13 \mathrm{~d}$ \\
\hline 3 & Sediment/Dunite reaction & 900 & 3 & $\sim 20$ & $\mathrm{Gt}+\mathrm{Cpx}+$ Si-rich melt & $\begin{array}{c}\mathrm{Phl}+\mathrm{Cpx}+\mathrm{OPx}+\mathrm{Ap}+ \\
\text { Fe-Ni Sulphides }\end{array}$ & $\mathrm{Ol}+\mathrm{Opx}+\mathrm{Mgs}$ & $14 \mathrm{~d}$ \\
\hline 4 & Sediment/Dunite reaction & 1000 & 3 & $\sim 30$ & $\mathrm{Gt}+$ Si-rich melt & $\mathrm{Phl}+\mathrm{CPx}+\mathrm{Opx}$ & $\mathrm{Ol}+\mathrm{Opx}$ & $4 \mathrm{~d}$ \\
\hline 5 & $\begin{array}{l}\text { Metasome meltıng } \\
\text { (Reaction zone of } \\
\text { experiment 3) }\end{array}$ & 1200 & 2 & $\sim 20$ & - & $\mathrm{Ol}+\mathrm{Opx}+\mathrm{Phl}+$ melt & - & $6 \mathrm{~h}$ \\
\hline
\end{tabular}

Mineral abbreviations: Gt—Garnet, Cpx-Clinopyroxene, Opx—Orthopyroxene, Phe—Phengite, Phl—Phlogopite, Ap—Apatite, Cc—Calcite, Coe—Coesite, Fe-Ni sulphides—Iron-Nickel sulphides, Si-rich melt-Silicate melt $>55 \mathrm{wt} \% \mathrm{SiO}_{2}$.

Table 2. Starting material and melt compositions.

\begin{tabular}{|c|c|c|c|c|c|c|c|c|c|c|c|}
\hline Sample & $\mathrm{K} / \mathrm{Na}$ & $\mathrm{Na}_{2} \mathrm{O}$ & $\mathrm{K}_{2} \mathrm{O}$ & $\mathrm{MnO}$ & $\mathrm{SiO}_{2}$ & $\mathrm{MgO}$ & $\mathrm{FeO}$ & $\mathrm{Al}_{2} \mathrm{O}_{3}$ & $\mathrm{CaO}$ & $\mathrm{TiO}_{2}$ & Total \\
\hline Sediment bulk & 1.57 & $1.78(6)$ & $2.46(9)$ & $2.17(9)$ & $54.9(4)$ & $3.93(6)$ & $3.6(2)$ & $17.8(1)$ & $13.5(2)$ & $0.82(3)$ & 100 \\
\hline Dunite bulk & - & 0.03 & 0.00 & 0.13 & 40.44 & 49.08 & 10.06 & 0.08 & 13.50 & 0.01 & 100 \\
\hline $3 \mathrm{GPa} / 800{ }^{\circ} \mathrm{C}$ Sediment/Dunite reaction melt & $2.9(6)$ & $1.6(4)$ & $3.9(4)$ & $0.13(4)$ & $75(1)$ & $0.4(4)$ & $0.4(1)$ & $15.3(4)$ & $2.5(6)$ & $0.25(2)$ & $89(1) *$ \\
\hline $3 \mathrm{GPa} / 850^{\circ} \mathrm{C}$ Sediment/Dunite reaction melt & $6(2)$ & $1.0(3)$ & $5(1)$ & $0.03(4)$ & $76(1)$ & $0.12(7)$ & $0.15(5)$ & $14.6(8)$ & $1.6(5)$ & $0.25(5)$ & $88(2) *$ \\
\hline $3 \mathrm{GPa} / 900{ }^{\circ} \mathrm{C}$ Sediment/Dunite reaction melt & $6(2)$ & $1.1(2)$ & $6.2(8)$ & $0.13(3)$ & $74.6(4)$ & $0.50(8)$ & $0.88(4)$ & $12.9(5)$ & $3.3(5)$ & $0.33(2)$ & $82(1)$ * \\
\hline $3 \mathrm{GPa} / 1000{ }^{\circ} \mathrm{C}$ Sediment/Dunite reaction melt & $4.0(5)$ & $1.3(2)$ & $4.5(1)$ & $0.9(1)$ & $56(1)$ & $5.5(3)$ & $3.2(2)$ & $16.1(2)$ & $11.3(7)$ & $1.03(7)$ & $81(1)$ * \\
\hline $2 \mathrm{GPa} / 1200{ }^{\circ} \mathrm{C}$ second-stage melting & $7.1(6)$ & $1.3(1)$ & $8.4(2)$ & $0.37(8)$ & $58(1)$ & $3(1)$ & $1.0(4)$ & $17.8(9)$ & $9(1)$ & $0.63(7)$ & $88(2)$ * \\
\hline
\end{tabular}

* Analytical totals, oxide compositions of glass measurements are normalized to $100 \mathrm{wt} \%$. The number in parentheses represents one standard deviation on the last digit. 
Table 3. Mineral compositions.

\begin{tabular}{|c|c|c|c|c|c|c|c|c|c|c|}
\hline Olivine & $\mathrm{Na}_{2} \mathrm{O}$ & $\mathrm{K}_{2} \mathrm{O}$ & $\mathrm{MnO}$ & $\mathrm{SiO}_{2}$ & $\mathrm{MgO}$ & $\mathrm{FeO}$ & $\mathrm{Al}_{2} \mathrm{O}_{3}$ & $\mathrm{CaO}$ & $\mathrm{TiO}_{2}$ & Total \\
\hline $3 \mathrm{GPa} / 900^{\circ} \mathrm{C}$ Sediment/Dunite reaction & $0.04(5)$ & $0.01(2)$ & $0.13(2)$ & $40.7(4)$ & $52.3(3)$ & $8.5(2)$ & $0.01(1)$ & $0.06(3)$ & $0.01(1)$ & 101(1) \\
\hline $3 \mathrm{GPa} / 1000{ }^{\circ} \mathrm{C}$ Sediment/Dunite reaction & $0.02(1)$ & $0.01(1)$ & $0.20(6)$ & $39.8(2)$ & $50.2(1)$ & $8.3(2)$ & $0.02(2)$ & $0.04(1)$ & $0.02(1)$ & $98.6(2)$ \\
\hline $2 \mathrm{GPa} / 1200{ }^{\circ} \mathrm{C}$ second-stage melting & $0.002(3)$ & $0.01(1)$ & $0.06(1)$ & $41.6(2)$ & $54.6(4)$ & $1.97(6)$ & $0.01(1)$ & $0.33(3)$ & $0.01(1)$ & $98.7(4)$ \\
\hline Phlogopite & $\mathrm{Na}_{2} \mathrm{O}$ & $\mathrm{K}_{2} \mathrm{O}$ & $\mathrm{MnO}$ & $\mathrm{SiO}_{2}$ & $\mathrm{MgO}$ & $\mathrm{FeO}$ & $\mathrm{Al}_{2} \mathrm{O}_{3}$ & $\mathrm{CaO}$ & $\mathrm{TiO}_{2}$ & Total \\
\hline $3 \mathrm{GPa} / 800^{\circ} \mathrm{C}$ Sediment/Dunite reaction & $0.30(7)$ & $8.40(9)$ & $0.10(3)$ & $43.6(7)$ & $26.0(5)$ & $1.13(9)$ & $12.7(4)$ & $0.6(5)$ & $0.59(3)$ & $95.0(9)$ \\
\hline $3 \mathrm{GPa} / 850^{\circ} \mathrm{C}$ Sediment/Dunite reaction & $0.15(4)$ & $9(1)$ & $0.04(3)$ & $43(1)$ & $24(2)$ & $3.7(5)$ & $13(1)$ & $0.2(3)$ & $0.7(2)$ & $94(1)$ \\
\hline $3 \mathrm{GPa} / 900^{\circ} \mathrm{C}$ Sediment/Dunite reaction & $0.5(1)$ & $9.5(2)$ & $0.10(3)$ & $41.5(6)$ & 24.1(5) & $3.7(1)$ & 14.1(4) & $0.2(4)$ & $1.4(1)$ & $95(1)$ \\
\hline $2 \mathrm{GPa} / 1200{ }^{\circ} \mathrm{C}$ second-stage melting & $0.2(1)$ & $10.4(7)$ & $0.09(5)$ & $42(2)$ & $24(4)$ & $1.0(2)$ & $14.7(5)$ & $1(1)$ & $1.4(2)$ & $96(2)$ \\
\hline Phengite & $\mathrm{Na}_{2} \mathrm{O}$ & $\mathrm{K}_{2} \mathrm{O}$ & $\mathrm{MnO}$ & $\mathrm{SiO}_{2}$ & $\mathrm{MgO}$ & $\mathrm{FeO}$ & $\mathrm{Al}_{2} \mathrm{O}_{3}$ & $\mathrm{CaO}$ & $\mathrm{TiO}_{2}$ & Total \\
\hline $3 \mathrm{GPa} / 800^{\circ} \mathrm{C}$ Sediment/Dunite reaction & $0.45(8)$ & $10.4(2)$ & $0.06(4)$ & $49.2(8)$ & $3.6(1)$ & $1.0(1)$ & $28.2(5)$ & $0.15(8)$ & $0.9(1)$ & $94.6(7)$ \\
\hline $3 \mathrm{GPa} / 850^{\circ} \mathrm{C}$ Sediment/Dunite reaction & $0.18(2)$ & $9.8(6)$ & $0.04(3)$ & $49.7(7)$ & $5.6(3)$ & $0.6(2)$ & $27.0(3)$ & $0.09(2)$ & $1.0(1)$ & $94.9(8)$ \\
\hline Clinopyroxene & $\mathrm{Na}_{2} \mathrm{O}$ & $\mathrm{K}_{2} \mathrm{O}$ & $\mathrm{MnO}$ & $\mathrm{SiO}_{2}$ & $\mathrm{MgO}$ & $\mathrm{FeO}$ & $\mathrm{Al}_{2} \mathrm{O}_{3}$ & $\mathrm{CaO}$ & $\mathrm{TiO}_{2}$ & Total \\
\hline $3 \mathrm{GPa} / 800^{\circ} \mathrm{C}$ Sediment/Dunite reaction & $3.0(6)$ & $0.2(3)$ & $0.31(6)$ & $53(3)$ & $13(3)$ & $1.9(6)$ & $8(2)$ & $16(1)$ & $0.23(7)$ & $96(4)$ \\
\hline $3 \mathrm{GPa} / 900^{\circ} \mathrm{C}$ Sediment/Dunite reaction & $1.4(4)$ & $0.1(1)$ & $0.4(2)$ & $53.8(8)$ & $16(1)$ & $2.3(4)$ & $5(2)$ & 21(1) & $0.21(9)$ & $100.3(5)$ \\
\hline $3 \mathrm{GPa} / 1000^{\circ} \mathrm{C}$ Sediment/Dunite reaction & $0.84(8)$ & $0.03(4)$ & $0.71(6)$ & $51.9(6)$ & $14.9(7)$ & $3.1(3)$ & $5(1)$ & $21.9(2)$ & $0.22(6)$ & $98.6(4)$ \\
\hline Orthopyroxene & $\mathrm{Na}_{2} \mathrm{O}$ & $\mathrm{K}_{2} \mathrm{O}$ & $\mathrm{MnO}$ & $\mathrm{SiO}_{2}$ & $\mathrm{MgO}$ & $\mathrm{FeO}$ & $\mathrm{Al}_{2} \mathrm{O}_{3}$ & $\mathrm{CaO}$ & $\mathrm{TiO}_{2}$ & Total \\
\hline $3 \mathrm{GPa} / 900^{\circ} \mathrm{C}$ Sediment/Dunite reaction & $0.03(4)$ & $0.4(9)$ & $0.30(7)$ & $57(1)$ & $36.7(6)$ & $5.1(4)$ & $1(1)$ & $0.15(2)$ & $0.08(4)$ & $100.9(4)$ \\
\hline $3 \mathrm{GPa} / 1000^{\circ} \mathrm{C}$ Sediment/Dunite reaction & $0.02(2)$ & $0.03(4)$ & $0.43(4)$ & $54(1)$ & $34.1(9)$ & $4.9(2)$ & $2.5(6)$ & $0.7(3)$ & $0.08(3)$ & $98(2)$ \\
\hline $2 \mathrm{GPa} / 1200{ }^{\circ} \mathrm{C}$ second-stage melting & $0.16(4)$ & $0.01(1)$ & $0.12(4)$ & $54.5(6)$ & $35.1(7)$ & $1.41(8)$ & $5.8(7)$ & $1.3(4)$ & $0.21(6)$ & $99.8(4)$ \\
\hline Garnet & $\mathrm{Na}_{2} \mathrm{O}$ & $\mathrm{K}_{2} \mathrm{O}$ & $\mathrm{MnO}$ & $\mathrm{SiO}_{2}$ & $\mathrm{MgO}$ & $\mathrm{FeO}$ & $\mathrm{Al}_{2} \mathrm{O}_{3}$ & $\mathrm{CaO}$ & $\mathrm{TiO}_{2}$ & Total \\
\hline $3 \mathrm{GPa} / 800^{\circ} \mathrm{C}$ Sediment/Dunite reaction & $0.2(1)$ & $0.2(3)$ & $7(2)$ & $39(4)$ & $5.9(5)$ & 12(1) & 21.3(6) & $11.7(8)$ & $0.9(2)$ & $99.4(1)$ \\
\hline $3 \mathrm{GPa} / 900{ }^{\circ} \mathrm{C}$ Sediment/Dunite reaction & $0.07(4)$ & $0.02(2)$ & $5(2)$ & $40.7(8)$ & 13(3) & $11(4)$ & $22.8(6)$ & $9(2)$ & $0.5(3)$ & $101.3(7)$ \\
\hline $3 \mathrm{GPa} / 1000{ }^{\circ} \mathrm{C}$ Sediment/Dunite reaction & $0.02(4)$ & $0.03(2)$ & $4.2(4)$ & $40.4(6)$ & $12(1)$ & $8.7(6)$ & $21.9(5)$ & $11.1(5)$ & $0.34(5)$ & $99.1(2)$ \\
\hline
\end{tabular}

The number in parentheses represents one standard deviation on the last digit. 
Trace element compositions of melts derived from the sediment were acquired from the 3 $\mathrm{GPa} / 1000{ }^{\circ} \mathrm{C}$ experiment, which contained large pools of melt that were easily measurable by LA-ICP-MS. This melt is strongly enriched in large ion lithophile (LILE), high field strength (HFSE), and rare earth elements (REE), and shows negative anomalies at $\mathrm{Nb}, \mathrm{P}$, and $\mathrm{Ti}$, which are inherited from the bulk sediment composition (Figure 5).

\subsection{Second-Stage Experiments}

The second-stage melting experiment was conducted on the phlogopite pyroxenite from the first stage experiment at $3 \mathrm{GPa} / 900{ }^{\circ} \mathrm{C}$ (Figure 1A, Supplementary Data Table S2), which showed the thickest metasome layer of all reaction experiments. As the phlogopite pyroxenite disintegrated upon transfer to the new capsule, the second-stage experiment was not layered (Figure 1E,F). The second-stage experiment was performed at $2 \mathrm{GPa} / 1200^{\circ} \mathrm{C}$, thermobaric conditions at which phlogopite pyroxenites are known to be partially molten [16]. At these conditions, a mixture of phlogopite, clinopyroxene, and orthopyroxene breaks down to form olivine and melt [16]. After the second-stage melting, the glass contains $\sim 57.7 \mathrm{wt} \% \mathrm{SiO}_{2}, \sim 8.4 \mathrm{wt} \% \mathrm{~K}_{2} \mathrm{O}, \sim 17.8 \mathrm{wt} \% \mathrm{Al}_{2} \mathrm{O}_{3}, 9.36 \mathrm{wt} \% \mathrm{CaO}$, and $1.33 \mathrm{wt} \% \mathrm{Na}_{2} \mathrm{O}$ (Table 2, Figure $3 \mathrm{~A}-\mathrm{D}$ ), with $\mathrm{K} / \mathrm{Na} \sim 7$ (Figure $4 \mathrm{~A}$ ). Olivine appears zoned with lower $\mathrm{FeO}$ rims, indicating Fe-loss due to contact of the melt with the Pt-capsule. However, $\mathrm{K}_{\mathrm{D}}(\mathrm{Fe} / \mathrm{Mg})_{\mathrm{Ol}} /(\mathrm{Fe} / \mathrm{Mg})_{\text {liq }}$ attain 0.14 at $\sim 10 \mathrm{wt} \% \mathrm{Na}_{2} \mathrm{O}+\mathrm{K}_{2} \mathrm{O}$, which is in accordance with $\mathrm{K}_{\mathrm{D}(\mathrm{ol} / \mathrm{liq})}$ decreasing with alkali content of the liquid [54]. The glass-composition was calculated to result from $20 \%$ batch melting of the metasome containing $21 \mathrm{wt} \%$ phlogopite, $71 \mathrm{wt} \%$ orthopyroxene, and $8 \mathrm{wt} \%$ clinopyroxene (Supplementary Data Tables S2 and S9).
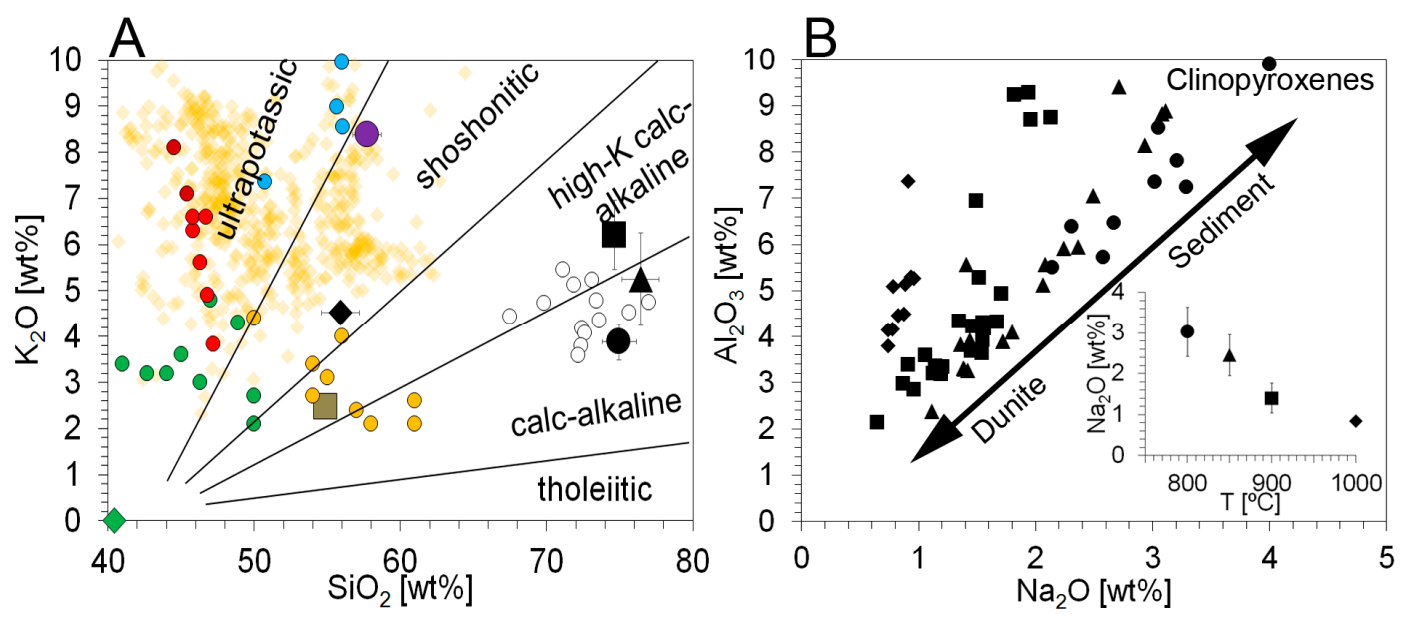

Figure 2. Melt (A) and clinopyroxene (B) compositions from reaction experiments (black circle $800{ }^{\circ} \mathrm{C}$; triangle $850{ }^{\circ} \mathrm{C}$; square $900{ }^{\circ} \mathrm{C}$; diamond $1000^{\circ} \mathrm{C}$ ) and second-stage melts (purple circle) of this study, compared with the sedimentary rock starting material (brown square), and published data: melts of phlogopite harzburgite and lherzolite (dark red and red circles [15]), hybridized rhyolite-peridotite (green circles [18]), glimmerite-harzburgite (blue circles [16]), hybridized phyllite-dunite (open white circles [20,31]), and phlogopite-amphibole peridotite (orange circles [55]). Natural post-collisional lavas with $\mathrm{K} / \mathrm{Na}>2$ (yellow diamonds [9]) are shown for comparison. Melts from reaction experiments at 3 $\mathrm{GPa} / 800-1000{ }^{\circ} \mathrm{C}$ are $\mathrm{SiO}_{2}$-rich and have moderately high $\mathrm{K}_{2} \mathrm{O}$. In contrast, second-stage experiment melts (purple dot) have higher $\mathrm{K}_{2} \mathrm{O}$ and lower $\mathrm{SiO}_{2}$, similar to natural ultrapotassic (UP) magmas. (B) Clinopyroxenes from reaction experiments show a range of compositions across the reaction zone, with higher $\mathrm{Na}_{2} \mathrm{O}$ and $\mathrm{Al}_{2} \mathrm{O}_{3}$ towards the former sedimentary rock. Symbols correspond to the experimental temperatures as in $(\mathrm{A})$. 

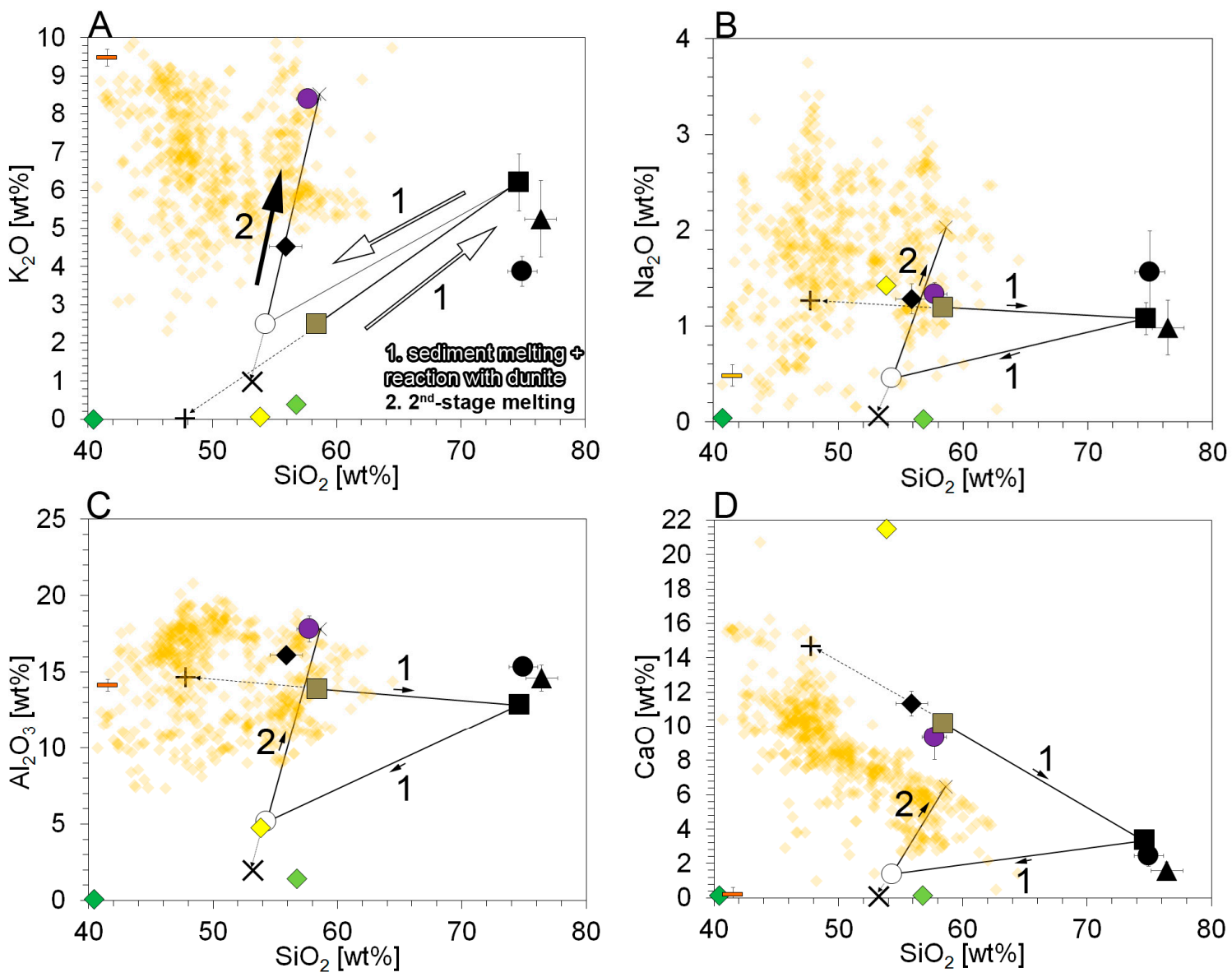

Figure 3. $\mathrm{K}_{2} \mathrm{O}(\mathbf{A}), \mathrm{Na}_{2} \mathrm{O}(\mathbf{B}), \mathrm{Al}_{2} \mathrm{O}_{3}(\mathbf{C})$, and $\mathrm{CaO}(\mathbf{D})$ versus $\mathrm{SiO}_{2}$ showing the melt evolution of the 3 $\mathrm{GPa} / 900{ }^{\circ} \mathrm{C}$ reaction and $2 \mathrm{GPa} / 1200{ }^{\circ} \mathrm{C}$ second-stage experiment as calculated by mass balance. In the first stage (white arrows), $40 \%$ melting of the sediment (brown square) generates an Si-rich melt (black square), leaving a residuum (black plus) comprising $40 \%$ garnet and $60 \%$ clinopyroxene (Supplementary Figure S1), a Ca-rich and K-poor composition. The Si-rich melt (black square) immediately reacts with olivine (dark green diamond), metasomatizing the adjacent dunite to phlogopite-pyroxenite (open circle). In the second stage, the metasomatized dunite melts to $20 \%$ crystallizing a residuum (black cross) comprising $16 \mathrm{wt} \%$ olivine, $56 \mathrm{wt} \%$ orthopyroxene, and $5 \mathrm{wt} \%$ phlogopite. Note that the calculated second-stage melt composition is close to the measured values (purple circle) for $\mathrm{K}_{2} \mathrm{O}$, $\mathrm{Al}_{2} \mathrm{O}_{3}$, and $\mathrm{SiO}_{2}(\mathrm{~A}, \mathrm{C})$. However, $\mathrm{Na}_{2} \mathrm{O}$ and $\mathrm{CaO}$ are over- and underestimated, respectively, probably owing to contamination by residual sediment during transfer of the metasomatized dunite to the second-stage experiment. Other symbols: melts of sediment (black circle $800{ }^{\circ} \mathrm{C}$; triangle $850{ }^{\circ} \mathrm{C}$; square $900{ }^{\circ} \mathrm{C}$; diamond $1000^{\circ} \mathrm{C}$ ), metasome (black star), reaction zone phases (phlogopite, orange rectangle; orthopyroxene, lime diamond; clinopyroxene, yellow diamond). 

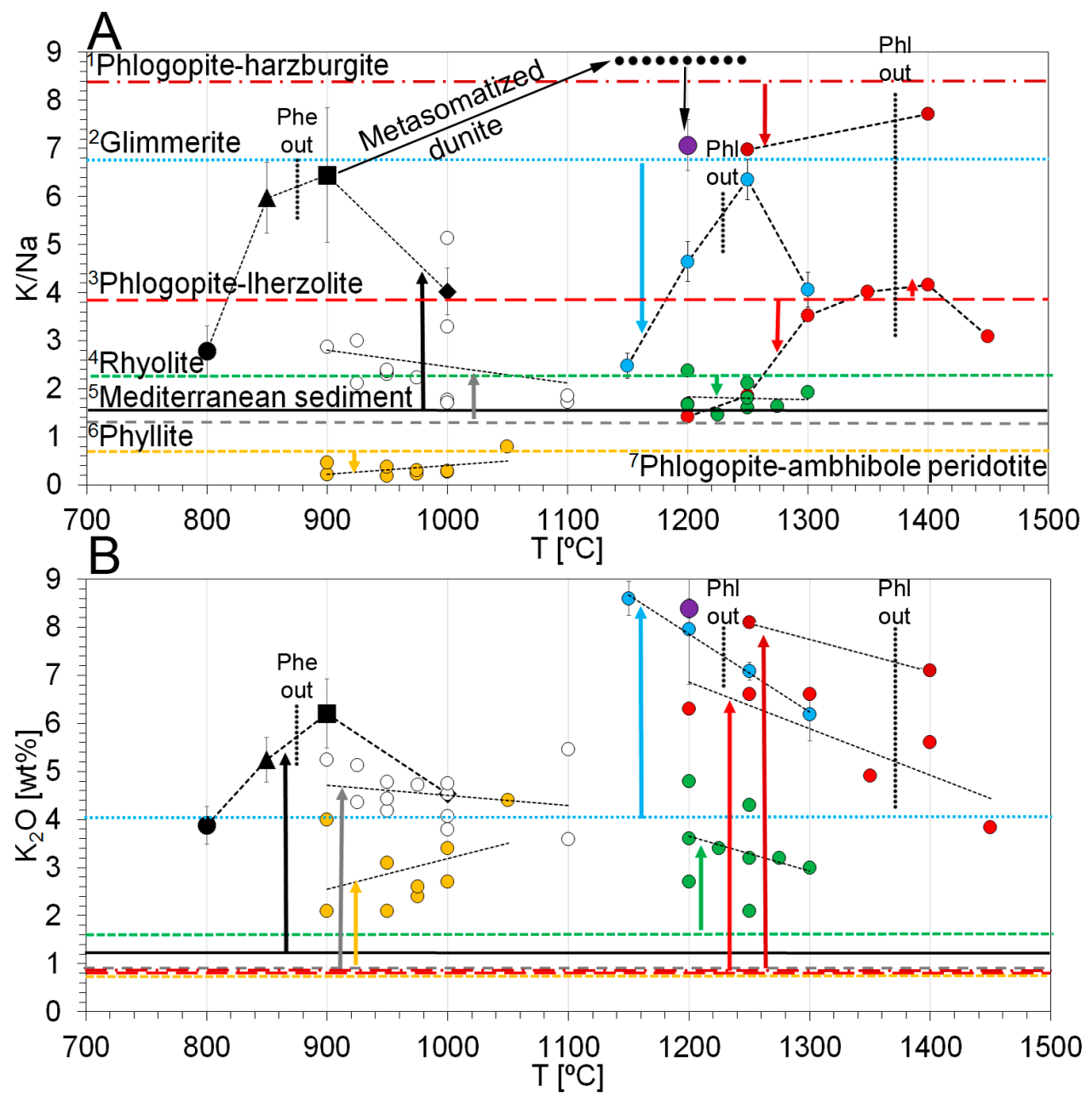

Figure 4. $\mathrm{K} / \mathrm{Na}(\mathrm{A})$ and $\mathrm{K}_{2} \mathrm{O}$ mass fractions (B) of melts versus experimental run temperature (black circle $800{ }^{\circ} \mathrm{C}$; triangle $850{ }^{\circ} \mathrm{C}$; square $900{ }^{\circ} \mathrm{C}$; diamond $1000{ }^{\circ} \mathrm{C}$ ) and second-stage melts (purple circle) of this study compared with published data for phlogopite harzburgite and lherzolite (dark red and red circles [15]), hybridized rhyolite/peridotite (green circles [19]), glimmerite/harzburgite (blue circles [16]), hybridized phyllite/dunite (open white circles [20,31]), and phlogopite-amphibole peridotite (orange circles [55]). (A) Horizontal lines represent starting materials and are color-matched to the symbols for the same experiments. $\mathrm{K} / \mathrm{Na}$ in melts shows peaks related to phengite breakdown at ca. $900{ }^{\circ} \mathrm{C}$ and phlogopite breakdown at $>1100{ }^{\circ} \mathrm{C}$. Only experiments at $<1100{ }^{\circ} \mathrm{C}$ generate melts in which $\mathrm{K} / \mathrm{Na}$ ratios exceed those of the starting materials (upward facing arrows). At $>1100^{\circ} \mathrm{C}$, the highest $\mathrm{K} / \mathrm{Na}$ ratios approach those of the starting material (downward facing arrows). The arrow labelled "Metasomatized dunite" connects the $900{ }^{\circ} \mathrm{C}$ reaction experiment and the calculated starting composition (thick dotted line: Supplementary Data Table S2) of the second-stage experiment at $1200{ }^{\circ} \mathrm{C}$. (B) $\mathrm{K}_{2} \mathrm{O}$ mass fractions of experimental charges generally decrease with increasing temperature. Phengite-buffered $\mathrm{K}_{2} \mathrm{O}$ mass fractions in siliceous melts first increase with temperature and then decrease after phengite breakdown. Maximum mass fractions of $\mathrm{K}_{2} \mathrm{O}$ are $<6 \mathrm{wt} \%$ for silica-rich melts (black symbols, white and green circles), while those buffered by phlogopite reach $<9 \mathrm{wt} \% \mathrm{~K}_{2} \mathrm{O}$ (blue, purple, and red circles).

\section{Discussion}

The generation of UP melts with $8.2 \mathrm{wt} \%-8.7 \mathrm{wt} \% \mathrm{~K}_{2} \mathrm{O}$, representing a $>4$ fold enrichment with respect to the original sediment source, is demonstrated unequivocally in our second-stage experiment. This is the first study that has generated UP melts with $\mathrm{K}_{2} \mathrm{O}>6 \mathrm{wt} \%$ from recycled crustal lithologies with $\mathrm{K}_{2} \mathrm{O}$ contents as low as $2.46 \mathrm{wt} \%$, thus confirming the applicability of this two-stage process of K-enrichment. In the following discussion, we first compare our study with previous experiments in 
similar systems and then discuss the application of our experiments to post-collisional lavas such as those occurring in the Alpine-Himalayan belt.

\subsection{Comparison with Previous Experimental Studies}

The recycling of crustal rocks into the mantle is a normal consequence of subduction and collision in the global tectonic cycle, constantly juxtaposing $\mathrm{SiO}_{2}$-oversaturated crustal rocks with $\mathrm{SiO}_{2}$-deficient mantle rocks. Isotopic and geochemical compositions of orogenic lavas in the Alpine-Himalaya orogenic belt (AHOB) undoubtedly document the effective recycling of crustal rocks to mantle depths $[10,29,43,56,57]$. The role of crustal recycling in the generation of UP post-collisional lavas differs between the two competing models presented above, with major uncertainties in terms of the process of hybridization and melt generation as follows:

(A) UP lavas form by melting of phlogopite pyroxenites and phlogopite peridotites that are abundant within the continental lithospheric mantle [58,59]; this has been successfully simulated by experiments with UP melts (Figure 2), $\mathrm{K}_{2} \mathrm{O} 6 \mathrm{wt} \%-12 \mathrm{wt} \%, \mathrm{MgO}>3 \mathrm{wt} \%$, and low $\mathrm{SiO}_{2}[15,16,60]$. Infiltrating melts derived from sediments form phlogopite-bearing pyroxenites at the expense of peridotites following the reaction melt + olivine $\rightarrow$ phlogopite + pyroxene $[23,35,61]$. This process is concentrated in the fore-arc, where hydrous sediments melt and infiltrate the mantle wedge because of their low solidus temperatures and high volatile contents [34].

(B) UP lavas form by direct melting and hybridization of crustal rocks with mantle peridotites in a single stage process at mantle depths [7,62]. Melt inclusions in garnets in ultrahigh-pressure paragneiss ( $5 \mathrm{GPa}$ ) are strongly enriched in potassium and resemble some types of shoshonitic magmas [63]. In this scenario, either the subducted crustal rocks mix with peridotites to form mélanges, or melts of subducted crustal rocks percolate and react with peridotites to form UP melts. This has previously been tested in experiments where a rhyolitic melt with as much as $6.4 \mathrm{wt} \% \mathrm{~K}_{2} \mathrm{O}$ was mixed with harzburgite [64], while others hybridized a phyllite $\left(1.9 \mathrm{wt} \% \mathrm{~K}_{2} \mathrm{O}\right)$ with dunite $[30,31]$. In both cases, experimental melts contain $<6 \mathrm{wt} \% \mathrm{~K}_{2} \mathrm{O}$, and $\mathrm{K} / \mathrm{Na}$ ratios of 4-5, much lower than the $12 \mathrm{wt} \% \mathrm{~K}_{2} \mathrm{O}$ and $\mathrm{K} / \mathrm{Na}$ up to 10 of UP lavas [2]. It is noteworthy that crustal lithologies have a solidus up to $500{ }^{\circ} \mathrm{C}$ lower than that of peridotite [21]. Therefore, at mantle temperatures of $>1200{ }^{\circ} \mathrm{C}$, crustal lithologies generate Si-rich high degree melts in which $\mathrm{K}_{2} \mathrm{O}$ is diluted. This is evident from experiments hybridizing rhyolite and peridotite at $1200-1350{ }^{\circ} \mathrm{C}[19,64]$, where the maximum $\mathrm{K}_{2} \mathrm{O}$ mass fraction of the melt $(\sim 7.4 \mathrm{wt} \%)$ is close to that of the rhyolite component in the starting material $(6.4 \mathrm{wt} \%)$. Even though these studies did not aim to reveal the origin of UP lavas, their work demonstrates that even high mass fractions of $\mathrm{K}_{2} \mathrm{O}$ in the starting material do not produce UP melts. In addition, $\mathrm{K} / \mathrm{Na}$ ratios are lower than in the bulk starting material at $>1100{ }^{\circ} \mathrm{C}$, as melting of crustal rocks at high mantle temperatures does not form any Na-bearing phases that can increase $\mathrm{K} / \mathrm{Na}$ ratios of the melt. All experimental melt compositions of sediment/peridotite hybridization so far fit this pattern [19,30,31,64], with $\mathrm{K} / \mathrm{Na}$ values of $1-2$ at $\geq 1100{ }^{\circ} \mathrm{C}$ (Figure $4 \mathrm{~A}$ ). In contrast, at $<1100{ }^{\circ} \mathrm{C}$, where temperatures are below that of the ambient mantle, experimental melts of either sedimentary rocks alone, or melts resulting from sediment/peridotite reaction, reach $\mathrm{K} / \mathrm{Na}$ values that exceed those of the starting material. This difference in behavior is induced by the interaction between phengite stability and $\mathrm{Na}_{2} \mathrm{O}$ content of residual clinopyroxene in the sediment layer: as in the case of melting of phlogopite, the highest $\mathrm{K} / \mathrm{Na}$ of experimental melts are reached after phengite breakdown (at $900^{\circ} \mathrm{C}$; Figure $4 \mathrm{~A}$ ) where all potassium is accommodated within the melt. However, at $<1100^{\circ} \mathrm{C}$, the melts are generally $\mathrm{Si}$-rich $\left(\mathrm{SiO}_{2}>70 \mathrm{wt} \%\right)$, thus high $\mathrm{K} / \mathrm{Na}$ values are bound to high $\mathrm{Si}$ - and low-Mg contents, unlike UP lavas. These results are in accordance with previous experiments by the authors of $[30,31]$, showing that melts produced by sediment + peridotite hybridization are mildly potassic and Si-rich. These may explain the origin of high-K calc-alkaline to shoshonitic lavas [7]. However, hybridization and melting of sediment and peridotite fail to explain the origin 
of the most K-enriched lavas-lamproites—which form in the same areas as mildly potassic lavas [9].

\subsection{First-Stage Experiments: Formation of Si-Rich Potassic Melts from a Phlogopite-Free Source}

Melting of sedimentary rocks in the first-stage experiments and reaction of these melts with depleted peridotite produced Si-rich melts with $\mathrm{K} / \mathrm{Na}>2$, while total $\mathrm{K}_{2} \mathrm{O}$ never exceeded $\sim 6 \mathrm{wt} \%$, consistent with hybridization experiments in previous studies that used continental crust material $[30,31]$. The melt derived from the sediment is highly enriched in LILE, HFSE, and REE, and trace elements plot within the field of post-collisional lavas with $\mathrm{K} / \mathrm{Na}>2$ (Figure 5) [9]. It shows negative anomalies at $\mathrm{Nb}, \mathrm{P}$, and $\mathrm{Ti}$, which are inherited from the bulk sediment composition. The formation of this Si-rich melt is explained by $40 \%$ batch melting of the bulk sediment composition (Supplementary Data Table S8):

$$
100 \mathrm{wt} \% \text { sediment } \rightarrow 40 \mathrm{wt} \% \text { Si-rich melt }+35 \mathrm{wt} \% \mathrm{cpx}+25 \mathrm{wt} \% \mathrm{gt}\left(\mathrm{R}^{2}=0.98\right) \text {. }
$$

The residue after melting of the sediment (clinopyroxene + garnet) of this first-stage process is rich in $\mathrm{Na}$ and $\mathrm{Ca}$ (Figure 3B,D). Clinopyroxenes from all first-stage reaction experiments are strongly zoned in $\mathrm{Na}$ across the reaction zone and reach highest $\mathrm{Na}_{2} \mathrm{O}$ mass fractions on the sediment side of the assemblage (Figure 2B). Additionally, $\mathrm{Na}$ is retained in clinopyroxene in the residue more effectively at a lower temperature (Figure 2B), corresponding to a decrease of $\mathrm{Na}_{2} \mathrm{O}$ partitioning from $\mathrm{D}_{\mathrm{Na} \text { (cpx/melt) }} \sim 2$ at $3 \mathrm{GPa} / 800{ }^{\circ} \mathrm{C}$ to $\mathrm{D}_{\mathrm{Na} \text { (cpx/melt) }} \sim 0.8$ at $3 \mathrm{GPa} / 1000{ }^{\circ} \mathrm{C}$. The formation of residual Na-rich clinopyroxene and the breakdown of phengite produce melt with high $\mathrm{K} / \mathrm{Na}$ ratios that peak at $\sim 6.5$ at $900{ }^{\circ} \mathrm{C}$ (Figure 4A). High $\mathrm{K} / \mathrm{Na}$ ratios are also facilitated by the high $\mathrm{Ca} / \mathrm{Na}$ composition of the sediment used in the experiments, which is probably typical for sediments during the late stages of ocean closure, where shallow basins above the calcite compensation depth facilitate the formation of carbonates. However, melts from the first-stage experiments at $<1000{ }^{\circ} \mathrm{C}$ are $\mathrm{SiO}_{2}$-rich (up to $79 \mathrm{wt} \%$ ), which does not match the definition of UP magmas, but is common for melts from crustal lithologies [30]. Thus, UP melt generation requires a process that first increases the $\mathrm{K} / \mathrm{Na}$ ratio of the melt at $<1000{ }^{\circ} \mathrm{C}$, which is facilitated by residual Na-rich clinopyroxene and high $\mathrm{D}_{\mathrm{Na}(\mathrm{cpx} / \mathrm{melt})}$, and then reduction of the silica content by reaction with ultramafic material. However, at $900-1000{ }^{\circ} \mathrm{C}$, hybridized melts are still Si-rich and show $\mathrm{MgO}$ contents $<1 \mathrm{wt} \%$, and hence do not satisfy the definition of ultrapotassic [30,31].

\subsection{Second-Stage Experiments: Formation of High K/Na Melts from a Metasomatized, Phlogopite-Bearing Mantle}

As hybridized melts of peridotite and crustal material are too low in $\mathrm{MgO}, \mathrm{K}_{2} \mathrm{O}$, and $\mathrm{K} / \mathrm{Na}$, and too high in $\mathrm{SiO}_{2}$, the formation of UP magma with $\mathrm{MgO}>3 \mathrm{wt} \%, \mathrm{~K} / \mathrm{Na}>2$, and $\mathrm{K}_{2} \mathrm{O}$ of $8 \mathrm{wt} \%-12 \mathrm{wt} \%$ from subducted crustal rocks must go beyond a single-stage mixing and melting process. Hence, a minimum of two stages is required: (1) Sediments or crustal rocks are subducted to mantle depth in a cool subduction setting where they melt, and the melt reacts with peridotite. At $<1000{ }^{\circ} \mathrm{C}$, the $\mathrm{SiO}_{2}$-rich melts are consumed as they react with olivine to form phlogopite in an incongruent crystallization reaction (Figure 1A-D): melt + olivine $\rightarrow$ phlogopite + pyroxene. (2) During subduction and collision, phlogopite-bearing peridotite is separated from the K-poor residue, which resides within the foundering slab, while the K-enriched fore-arc is heated by rising asthenospheric mantle. The phlogopite pyroxenite melts at $>1100{ }^{\circ} \mathrm{C}$ to produce UP melts with $\mathrm{MgO}>3 \mathrm{wt} \%, \mathrm{~K} / \mathrm{Na}>2$, and $\mathrm{K}_{2} \mathrm{O}$ of $8 \mathrm{wt} \%-12 \mathrm{wt} \%$.

The phlogopite-bearing metasome forms in the first stage (Figure 3), and because the melt is silica-oversaturated, the reaction with olivine forms pyroxene in addition to phlogopite [24]. According to mass balance calculations (Supplementary Data Table S9), melt infiltration in the $3 \mathrm{GPa} / 900{ }^{\circ} \mathrm{C}$ experiment leads to the following reaction:

$$
40 w t \% \text { Si-rich melt }+60 w t \% \text { ol } \rightarrow 71 w t \% o p x+21 w t \% p h l+8 w t \% c p x\left(R^{2}=0.997\right) .
$$


However, the spatial separation of phlogopite from orthopyroxene in the experimental reaction zones implies that this reaction occurs stepwise: the incongruent crystallization of phlogopite leads to the emergence of an $\mathrm{SiO}_{2}$-rich fluid that migrates and reacts with olivine to cause the crystallization of orthopyroxene beyond the phlogopite-enriched layer. The initial silica-rich melt would produce orthopyroxene barriers that limit the width of the reaction zone [31], whereas fluid is much more mobile and infiltrates more quickly along olivine grain boundaries. This explains the observation that orthopyroxene veins protrude beyond the metasome into the dunite (Figure 1A-D; Supplementary Figure S2).

The UP melt of the second-stage experiment can be calculated to correspond to a $20 \%$ batch melt of the metasome within the dunite (Supplement Data Table S10):

$$
\begin{gathered}
100 \mathrm{wt} \% \text { metasome }(71 \mathrm{wt} \% \mathrm{opx}+21 \mathrm{wt} \% \mathrm{phl}+8 \mathrm{wt} \% \mathrm{cpx}) \rightarrow 20 \mathrm{wt} \% \text { UP melt } \\
+56 \mathrm{wt} \% \mathrm{opx}+19 \mathrm{wt} \% \mathrm{ol}+5 \mathrm{wt} \% \mathrm{phl}\left(\mathrm{R}^{2}=0.999\right) .
\end{gathered}
$$

Reaction (3) produces UP melt and olivine by consuming phlogopite, clinopyroxene, and orthopyroxene of the phlogopite-pyroxenite metasome. The melting of phlogopite produces melts with potassium contents similar or higher than those of phlogopite in the source rock, as $\mathrm{K}_{2} \mathrm{O}$ is buffered by phlogopite at around $7 \mathrm{wt} \%-9 \mathrm{wt} \% \mathrm{~K}_{2} \mathrm{O}[16,60]$. Incongruent melting of phlogopite produces olivine or orthopyroxene depending on the pressure [18], which itself causes an increase in $\mathrm{K}_{2} \mathrm{O}$ in the melt [65]. The trend of increasing $\mathrm{K} / \mathrm{Na}$ with the degree of melting is also controlled by clinopyroxene as it changes its composition from Na-enriched to Na-depleted with increasing temperature [16]. As a result, the highest $\mathrm{K} / \mathrm{Na}$ values in the melt are achieved at intermediate temperatures when phlogopite breaks down (Figure 4A). Hence, high K/Na ratios in UP magmas are inherited from their metasomatized source and reflect the relative proportions of clinopyroxene and phlogopite. $\mathrm{The}^{\mathrm{SiO}} 2$ mass fractions reach values of $\sim 57.7 \mathrm{wt} \%$ for the second-stage melts, which are in accordance with melting of a pure pyroxenite assemblage [28].

The dotted black line in Figure $4 \mathrm{~A}$ shows the calculated $\mathrm{K} / \mathrm{Na}$ of $\sim 8.9$ for the phlogopite pyroxenite that was estimated from the modal abundance of phlogopite and clinopyroxene within the reaction zone (Supplementary Data Table S2). As the metasome formed by the reaction of melt with olivine, which contains neither $\mathrm{K}$ nor $\mathrm{Na}$, its $\mathrm{K} / \mathrm{Na}$ is inherited entirely from the infiltrating melt, which reaches $\mathrm{K} / \mathrm{Na} \sim 6.4$. The difference between $\mathrm{K} / \mathrm{Na}$ values of 6.4 and 8.9 may be a result of loss of clinopyroxene during transfer to the second-stage capsule. This transfer is depicted by the "metasomatized dunite" arrow in Figure 4A, which symbolizes the metasome formation and mechanical separation. Melting of the metasome produced UP melts with $\mathrm{K} / \mathrm{Na}$ of $\sim 7$ and $\mathrm{K}_{2} \mathrm{O}$ mass fractions of $\sim 8 \mathrm{wt} \%$. While the $\mathrm{K} / \mathrm{Na}$ ratio is similar to the first-stage silica-rich melt that metasomatized the dunite, the extreme enrichment of $\mathrm{K}_{2} \mathrm{O}$ during second-stage melting (3) was facilitated by physical separation from the K-poor residual sediment that formed by reaction (1). However, experimental melts are enriched in $\mathrm{CaO}$ by $2 \mathrm{wt} \%-3$ $\mathrm{wt} \%$ at a given mass fraction of $\mathrm{SiO}_{2}$ (Figure 3D) compared with natural post-collisional lavas, which is likely because of initial $\mathrm{Ca} / \mathrm{Na}$ of the Ca-rich sediment.

Owing to the small scale of the melt pools, trace elements could only be obtained from the 3 $\mathrm{GPa} / 1000{ }^{\circ} \mathrm{C}$ experiment, which had melt pools beneath the reaction zone that were large enough for analysis by LA-ICP-MS. However, as the metasome formed by a reaction of $40 \mathrm{wt} \%$ melt of sediment with $60 \mathrm{wt} \%$ olivine (reaction 2), bulk trace element concentrations of the metasome can be calculated (Figure 5A, Supplementary Data Table S14). Also, trace element concentrations of the second-stage melt (reaction 3) can be modelled using the non-modal batch melting equation [66] with partition coefficients determined from partial melting of phlogopite pyroxenite [16]. While the bulk metasome composition shows concentrations below those observed in post-collisional lavas [9], 10-30\% batch melts of it lie within the observed compositional range (Figure 5A). 


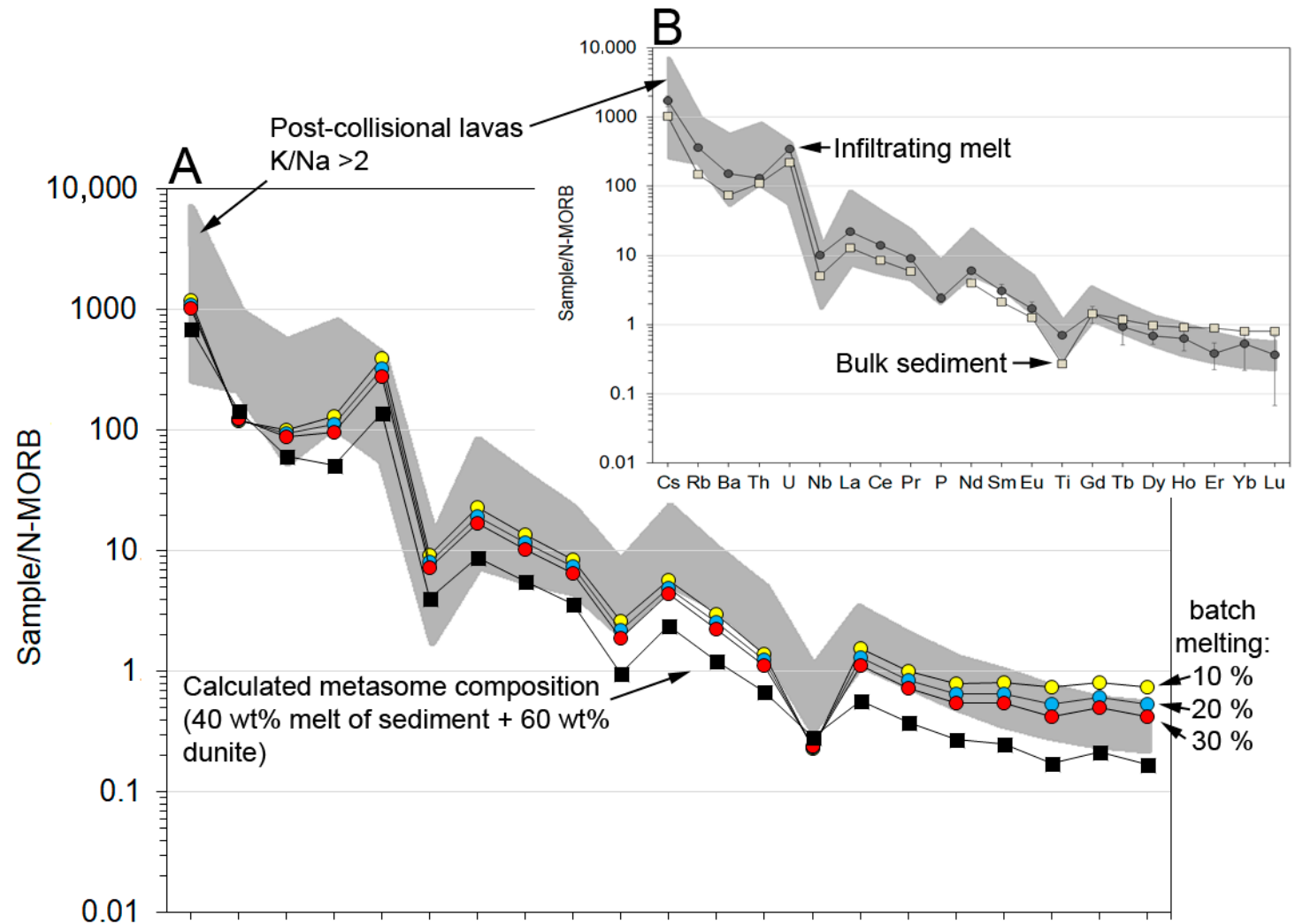

Cs Rb Ba Th U Nb La Ce Pr P NdSmEu Ti Gd Tb Dy Ho Er Yb Lu
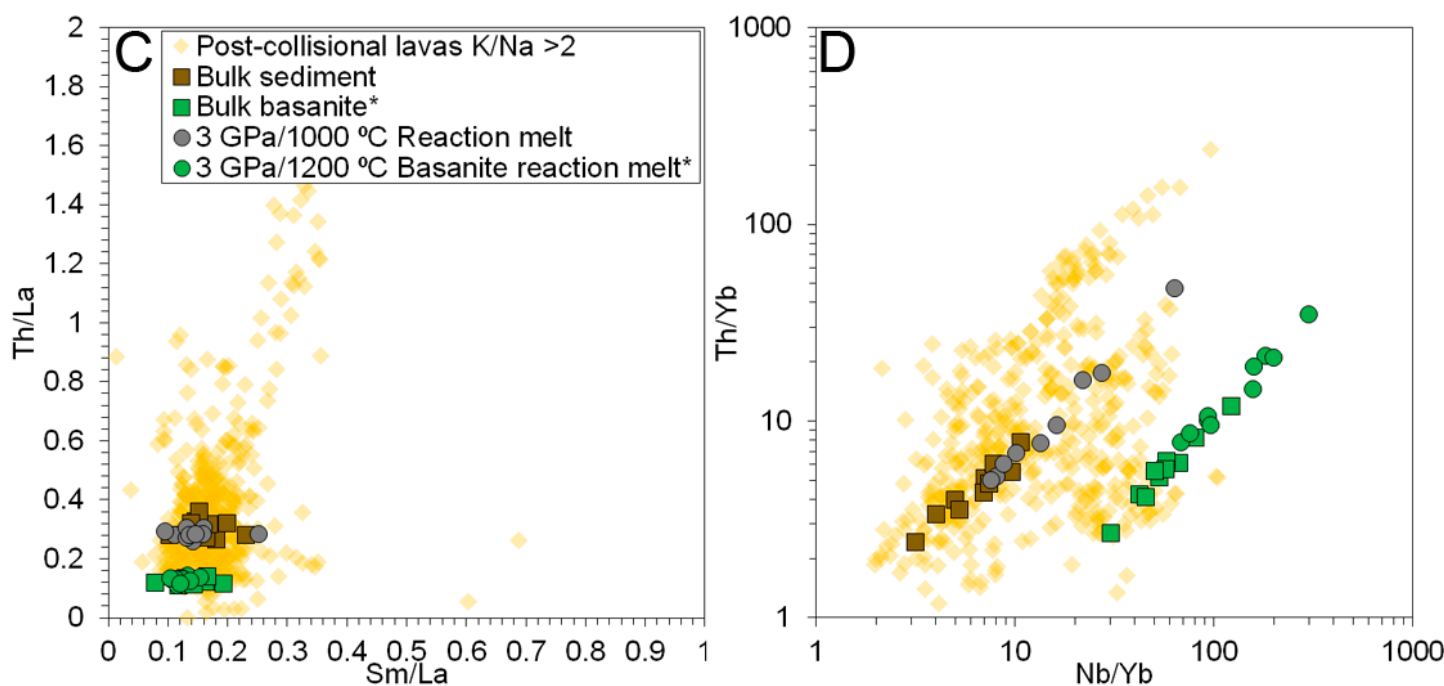

Figure 5. N-MORB normalized trace element compositions of (A) modelled batch melt compositions and (B) starting materials [67] (grey squares, sediment) compared with experimental melts (grey circles, $3 \mathrm{GPa} / 1000{ }^{\circ} \mathrm{C}$ ) and post-collisional lavas (shaded area) [9]. The sediment/dunite reaction melts (B) are rich in $\mathrm{Cs}, \mathrm{Rb}$, and $\mathrm{Ba}$, and show negative anomalies at $\mathrm{Nb}, \mathrm{P}$, and $\mathrm{Ti}$, similar to post-collisional lavas with $\mathrm{K} / \mathrm{Na}>2$. (A) Forty weight percent melt of sediment reacts with $60 \mathrm{wt} \%$ dunite to form the calculated metasome composition. Batch melting of the metasome (10-30\%) increases the trace element mass fractions to values observed within post-collisional lavas. (C) Th/La versus $\mathrm{Sm} /$ La shows experimental $3 \mathrm{GPa} / 1000^{\circ} \mathrm{C}$ sediment/dunite reaction melts at $\mathrm{Th} / \mathrm{La} 0.2-0.6$, plotting with the bulk of post-collisional lavas [9], while peridotite melts such as basanite/dunite reaction melts plot at $\mathrm{Th} / \mathrm{La}$ $<0.2$ [53]. (D) $\mathrm{Th} / \mathrm{Yb}$ versus $\mathrm{Nb} / \mathrm{Yb}$ of sediment/dunite reaction melts plot with post-collisional lavas, while basanite/dunite reaction melts attain higher $\mathrm{Nb} / \mathrm{Yb}$ ratios and plot largely outside the field of post-collisional lavas [53]. 
Post-collisional lavas show a strong enrichment of Th over REE. Reaction melts in the $3 \mathrm{GPa} / 1000$ ${ }^{\circ} \mathrm{C}$ experiment plot in $\mathrm{Th} / \mathrm{La}$ versus $\mathrm{Sm} / \mathrm{La}$ and $\mathrm{Th} / \mathrm{Yb}$ versus $\mathrm{Nb} / \mathrm{Yb}$ within the field of post-collisional lavas [9], which attain high $\mathrm{Th} / \mathrm{La}$ and $\mathrm{Th} / \mathrm{Yb}$ (Figure 5C,D). In contrast, melts of peridotite and basanite/dunite reaction melts [53] show low Th/La and Th/Yb. The composition of the $3 \mathrm{GPa} / 1000$ ${ }^{\circ} \mathrm{C}$ sediment/dunite reaction melt scatter around the sediment composition at $\mathrm{Th} / \mathrm{La} \sim 0.3$ and $\mathrm{Sm} / \mathrm{La}$ 0.1-0.2 and suggest that heterogeneities within the source components lead to variations within post-collisional lavas (Figure $5 \mathrm{C}$ ). $\mathrm{Th} / \mathrm{Yb}$ versus $\mathrm{Nb} / \mathrm{Yb}$ are positively correlated in experimental samples and post-collisional lavas (Figure 5D), whereby melts with no crustal input have the lowest $\mathrm{Th} / \mathrm{Yb}$ and high $\mathrm{Nb} / \mathrm{Yb}$, as evident from the basanite/dunite reaction experiments [53]. Nevertheless, $\mathrm{Th} /$ La ratios of lamproites reach high values of $>1$ (Figure 5C) that are yet unmatched by experimental melt compositions [20], suggesting either an enigmatic process for Th/La fractionation or another subducted protolith.

Our results demonstrate a general process where subducted sediments lead to mantle metasomatism and K-enrichment. It is very likely that different sediment compositions and varying degrees of melting of the sediment will lead to less, or even more, K-enrichment of the fore-arc mantle. On balance, we demonstrate that Mediterranean sediment leads to metasomatism and the formation of K-rich melts similar to high-Si lamproites found in the Mediterranean area [28].

\subsection{Implications for the Formation of Post-Collisional Lavas}

The sediment/dunite reaction of the first-stage experiments produced melts with $3 \mathrm{wt} \%-6 \mathrm{wt} \%$ $\mathrm{K}_{2} \mathrm{O}$ and $\mathrm{SiO}_{2}$ varying from $55 \mathrm{wt} \%-79 \mathrm{wt} \%$ with decreasing temperature from 1000 to $800{ }^{\circ} \mathrm{C}$. Their major element (Figures 2 and 3 ) and trace element concentrations (Figure 5B) are in accordance with the formation of post-collisional lavas by model (B) that are Si-rich and show $\mathrm{K}_{2} \mathrm{O}$ concentrations similar to shoshonites and high-K calc-alkaline lavas [9]. Although melt inclusions in garnet indicate that ultrahigh-pressure melting of paragneiss may produce melts with high Th/U and LILE as well as fractionating LREE from HREE, the K-enrichment by this process is insufficient to produce lamproites; melts are more similar to some types of shoshonite [63] or granites [68]. None of the first-stage experiments of this study produced K-rich melts that are comparable to lamproites, which coexist with shoshonites and high-K calc-alkaline lavas, nor have other experiments that investigated sediment-peridotite hybridization $[30,31]$. The most K-enriched crustal rocks, rhyolites and granites, will also produce only mildly potassic lavas if they hybridize with peridotites $[19,64]$. Hence, the direct melting of crustal lithologies and hybridization with mantle rocks proposed in model (B) is only able to explain the formation of mildly potassic, Si-rich, post-collisional lavas.

However, it must be emphasized that post-collisional lavas of shoshonitic and high-K calc-alkaline composition occur concurrently in time and space with extremely K-enriched lamproites in several volcanic provinces of the AHOB [28,29]. In two well-documented examples, extremely K-enriched lavas were erupted in a fore-arc setting, induced by slab-rollback, and indicate a strongly metasomatized lithospheric fore-arc mantle [33,34]. Accordingly, the simultaneous appearance of lamproites with other less K-rich lavas suggests that they share a similar source and represent an end-member with the highest proportion of metasomatized mantle (phlogopite pyroxenite) in their source. Melts of phlogopite pyroxenites, as demonstrated by the second-stage melting experiment, produce melts with a high $\mathrm{K}_{2} \mathrm{O}$ mass fraction of $8 \mathrm{wt} \%-9 \mathrm{wt} \%$ and high $\mathrm{K} / \mathrm{Na}$ of $\sim 7$, which are comparable to post-collisional lavas with lamproitic compositions (Figures 2 and 4), in accordance with previous studies on phlogopite pyroxenite melting [16]. Batch-melting modelling of the second-stage experiments shows that $20 \%$ melting of phlogopite pyroxenite satisfies major and trace element composition of high-K post-collisional lavas (Figures 2 and 5). The high degree of melting (20\%) contrasts with the extremely low-degree melts $(<2 \%)$ that are required to form high-K alkaline magmas from a peridotitic source (e.g., [5]) and better explains high volumes of K-rich lavas observed in areas such as the Roman Province (e.g., [69]). However, the overall scarcity of extremely ultrapotassic lavas such as lamproites may be explained by the rarity of K-rich mantle metasomes. 


\section{Conclusions}

The re-use of the sediment-melt metasomatized dunite confirms that two-stage formation can account for UP magmatism with $\mathrm{K}_{2} \mathrm{O}>6 \mathrm{wt} \%$ involving significant contributions from silicic crustal components, as seen in almost all post-collisional UP magmas. Extremely K-enriched magmas require a modally metasomatized mantle enriched in phlogopite $[8,9,11,34]$. This enrichment probably takes place during subduction when sediment starts to melt at $\sim 675^{\circ} \mathrm{C}$, forming high $\mathrm{K} / \mathrm{Na}$ dacitic/rhyolitic melts that react with wall-rock peridotite. Phlogopite is formed by incongruent crystallization during this reaction, consuming the melt (Figure 6A). The residue of the melted sediment attains a low $\mathrm{K} / \mathrm{Na}$ ratio and crystallizes $\mathrm{Na}-\mathrm{Al}$ rich clinopyroxene, releasing melt with high $\mathrm{K} / \mathrm{Na}$. After metasomatism and enrichment of the fore-arc in $\mathrm{K} / \mathrm{Na}$, the low $\mathrm{K} / \mathrm{Na}$ residue is subducted to greater depths and temperatures where it may contribute to arc magmas with $\mathrm{K} / \mathrm{Na}<1$ (Figure $6 \mathrm{~A}$ ).
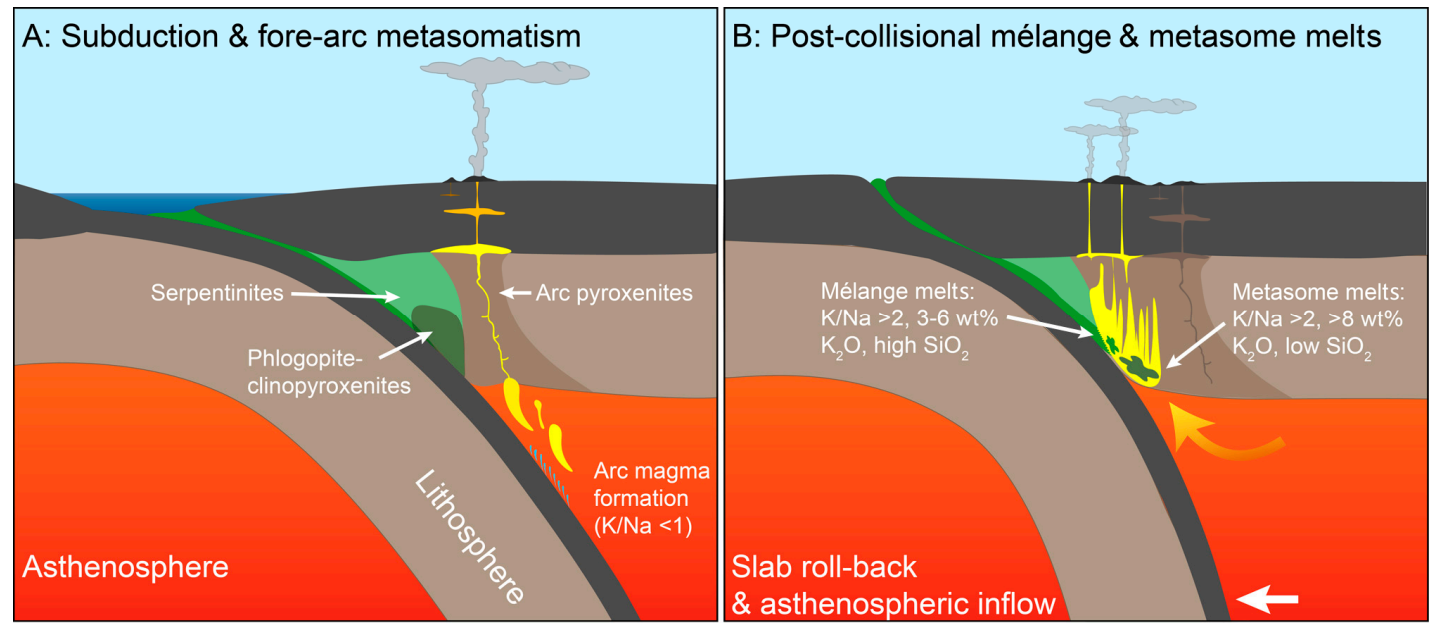

Figure 6. Model for the genesis of post-collisional UP magmatism. (A) Fore-arc mantle is metasomatized by melts of subducting sedimentary rocks; melts have $\mathrm{K} / \mathrm{Na}$ ratios $>2$ and react with depleted mantle to form phlogopite clinopyroxenites, leaving a K-depleted residuum that contributes at deeper levels to arc magmas with low $\mathrm{K} / \mathrm{Na}$ ratios of $<1$. (B) After slab-rollback (and possibly during continental collision), upwelling asthenosphere introduces heat and melts the metasomes and mélanges. These second-stage magmas are ultrapotassic in composition ( $/ \mathrm{Na}>2, \mathrm{~K}_{2} \mathrm{O} 3 \mathrm{wt} \%-6 \mathrm{wt} \%$ from crust, and mélanges and up to $>8 \mathrm{wt} \%$ for metasome melts).

After subduction ceases, slab-rollback and/or break-off allows access of hot asthenospheric mantle to shallow levels of the fore-arc mantle, thereby heating the modally metasomatized peridotite (Figure 6B). Partial melting of the phlogopite-enriched metasome now produces UP melts with $\mathrm{K}_{2} \mathrm{O}$ contents of $6 \mathrm{wt} \%$ to $12 \mathrm{wt} \%$. In addition, large amounts of subducted crustal lithologies incorporated into newly-formed lithosphere [28] may directly melt to produce siliceous potassic rocks with lower $\mathrm{K}_{2} \mathrm{O}(<6 \mathrm{wt} \%$; Figure 6).

However, if the rise of the hot asthenospheric mantle fails to induce melting of the metasomes, they may reside within the lithospheric mantle until they are "activated" at a much later stage. This later activation could be induced by geodynamic processes different to the post-collisional setting, including heat introduction by mantle plumes, or rifting and associated decompression melting. Potassic magmatism that exhibits the involvement of subducted sediments remote to young orogens in locations such as Gaussberg; Antarctica [70,71]; or West Kimberley, Australia [72,73] would fit this scenario.

Supplementary Materials: The following are available online at http:/www.mdpi.com/2075-163X/10/1/41/s1, Figure S1: Residual sediment of the $3 \mathrm{GPa} / 900{ }^{\circ} \mathrm{C}$ experiment containing $\sim 60 \%$ clinopyroxene (grey), $\sim 40 \%$ garnet (light grey), and interstitial glass (dark grey) as estimated by Fiji (imagej)., Figure S2: Orthopyroxene-veines in 
dunite of the $3 \mathrm{GPa} / 900{ }^{\circ} \mathrm{C}$ experiment containing $22 \%$ orthopyroxene (grey) and $78 \%$ olivine (red) as estimated by Fiji (imagej). The metasomatized sediment is located below the phlogopite layer, Table S1: Glass averages. Table S2: Starting materials, Table S3: $3 \mathrm{GPa} / 800 \mathrm{C}$ Reaction Experiment. Table S4: $3 \mathrm{GPa} / 850 \mathrm{C}$ Reaction Experiment, Table S5: 3 GPa/900 C Reaction Experiment, Table S6: 3 GPa/1000 C Reaction Experiment. Table S7: 2nd-stage melting experiment $2 \mathrm{GPa} / 1200 \mathrm{C}$, Table S8: Mass balance of $3 \mathrm{GPa} / 900 \mathrm{C}$ sediment melt, Table S9: Mass balance of $3 \mathrm{GPa} / 900 \mathrm{C}$ reaction zone, Table S10: Mass balance of 2nd-stage experiment using the metasomatized dunite as starting composition, Table S11: Reference materials for LA-ICP-MS quality control, Table S12: Solution ICP-MS measurements, Table S13: Trace elements of $3 \mathrm{GPa} / 1000 \mathrm{C}$ sediment-dunite reaction experiment, Table S14: Trace element modelling.

Author Contributions: Conceptualization, M.W.F., D.P., B.X., and S.F.F.; Methodology, M.W.F. and S.B.; Formal Analysis, M.W.F., S.B. and R.M.-K.; Writing-Original Draft Preparation, M.W.F., D.P., B.X., and S.F.F.; All authors have read and agreed to the published version of the manuscript.

Funding: This work is part of the lead author's (M.W.F.) PhD thesis supported by an Australian Government International Postgraduate Research Scholarship (IPRS) and Postgraduate Research Fund (PGRF). D.P. was supported through the Deutsche Forschungsgemeinschaft (DFG) project PR 1072/9-1. S.F.F. is funded by ARC grant FL 180100134.

Acknowledgments: We gratefully acknowledge Qing Xiong for providing the dunite sample ZD11-53 used in the experiments. The International Ocean Discovery Project (IODP) supported this study in providing the Mediterranean marine sediment sample from sampling site 161-976. This is contribution 1417 from the ARC Centre of Excellence for Core to Crust Fluid Systems (http://www.ccfs.mq.edu.au) and 1360 in the GEMOC Key Centre (http://www.gemoc.mq.edu.au).

Conflicts of Interest: The authors declare no conflict of interest.

\section{References}

1. Le Maitre, R.W.; Streckeisen, A.; Zanettin, B.; Le Bas, M.J.; Bonin, B.; Bateman, P. Igneous Rocks: A Classification and Glossary of Terms: Recommendations of the International Union of Geological Sciences Subcommission on the Systematics of Igneous Rocks; Cambridge University Press: Cambridge, UK, 2005; ISBN 1139439391.

2. Mitchell, R.H.; Bergman, S.C. Petrology of Lamproites; Springer Science \& Business Media: Berlin/Heidelberg, Germany, 1991; ISBN 030643556X.

3. Foley, S.; Venturelli, G.; Green, D.H.; Toscani, L. The ultrapotassic rocks: Characteristics, classification, and constraints for petrogenetic models. Earth-Sci. Rev. 1987, 24, 81-134. [CrossRef]

4. Hofmann, A.W. Chemical differentiation of the Earth: The relationship between mantle, continental crust, and oceanic crust. Earth Planet. Sci. Lett. 1988, 90, 297-314. [CrossRef]

5. Novella, D.; Frost, D.J.; Hauri, E.H.; Bureau, H.; Raepsaet, C.; Roberge, M. The distribution of $\mathrm{H}_{2} \mathrm{O}$ between silicate melt and nominally anhydrous peridotite and the onset of hydrous melting in the deep upper mantle. Earth Planet. Sci. Lett. 2014, 400, 1-13. [CrossRef]

6. Foley, S. Vein-plus-wall-rock melting mechanisms in the lithosphere and the origin of potassic alkaline magmas. Lithos 1992, 28, 435-453. [CrossRef]

7. Campbell, I.H.; Stepanov, A.S.; Liang, H.-Y.; Allen, C.M.; Norman, M.D.; Zhang, Y.-Q.; Xie, Y.-W. The origin of shoshonites: New insights from the Tertiary high-potassium intrusions of eastern Tibet. Contrib. Mineral. Petrol. 2014, 167, 983. [CrossRef]

8. Conticelli, S.; Avanzinelli, R.; Ammannati, E.; Casalini, M. The role of carbon from recycled sediments in the origin of ultrapotassic igneous rocks in the Central Mediterranean. Lithos 2015, 232, 174-196. [CrossRef]

9. Prelević, D.; Foley, S.F.; Romer, R.; Conticelli, S. Mediterranean Tertiary lamproites derived from multiple source components in postcollisional geodynamics. Geochim. Cosmochim. Acta 2008, 72, 2125-2156. [CrossRef]

10. Xu, B.; Griffin, W.L.; Xiong, Q.; Hou, Z.-Q.; O’Reilly, S.Y.; Guo, Z.; Pearson, N.J.; Gréau, Y.; Yang, Z.-M.; Zheng, Y.-C. Ultrapotassic rocks and xenoliths from South Tibet: Contrasting styles of interaction between lithospheric mantle and asthenosphere during continental collision. Geology 2017, 45, 51-54. [CrossRef]

11. Lustrino, M. What 'anorogenic'igneous rocks can tell us about the chemical composition of the upper mantle: Case studies from the circum-Mediterranean area. Geol. Mag. 2011, 148, 304-316. [CrossRef]

12. Foley, S.F.; Prelevic, D.; Rehfeldt, T.; Jacob, D.E. Minor and trace elements in olivines as probes into early igneous and mantle melting processes. Earth Planet. Sci. Lett. 2013, 363, 181-191. [CrossRef]

13. Foley, S. Petrological characterization of the source components of potassic magmas: Geochemical and experimental constraints. Lithos 1992, 28, 187-204. [CrossRef] 
14. Safonov, O.; Butvina, V.; Limanov, E. Phlogopite-Forming Reactions as Indicators of Metasomatism in the Lithospheric Mantle. Minerals 2019, 9, 685. [CrossRef]

15. Condamine, P.; Médard, E.; Devidal, J.-L. Experimental melting of phlogopite-peridotite in the garnet stability field. Contrib. Mineral. Petrol. 2016, 171, 95. [CrossRef]

16. Förster, M.W.; Prelević, D.; Schmück, H.R.; Buhre, S.; Veter, M.; Mertz-Kraus, R.; Foley, S.F.; Jacob, D.E. Melting and dynamic metasomatism of mixed harzburgite+ glimmerite mantle source: Implications for the genesis of orogenic potassic magmas. Chem. Geol. 2017, 455, 182-191. [CrossRef]

17. Condamine, P.; Médard, E. Experimental melting of phlogopite-bearing mantle at $1 \mathrm{GPa}$ Implications for potassic magmatism. Earth Planet. Sci. Lett. 2014, 397, 80-92. [CrossRef]

18. Foley, S.F.; Musselwhite, D.S.; van der Laan, S.R. Melt Compositions from Ultramafic Vein Assemblages in the Lithospheric Mantle: A Comparison of Cratonic and Non-Cratonic Settings. In Proceedings of the 7th International Kimberlite Conference Foley, Cape Town, South Africa, 11-17 April 1998; Red Roof Design Cape Town: Cape Town, South Africa, 1999.

19. Mallik, A.; Dasgupta, R.; Tsuno, K.; Nelson, J. Effects of water, depth and temperature on partial melting of mantle-wedge fluxed by hydrous sediment-melt in subduction zones. Geochim. Cosmochim. Acta 2016, 195, 226-243. [CrossRef]

20. Wang, Y.; Prelević, D.; Buhre, S.; Foley, S.F. Constraints on the sources of post-collisional K-rich magmatism: The roles of continental clastic sediments and terrigenous blueschists. Chem. Geol. 2017, 455, 192-207. [CrossRef]

21. Hermann, J.; Spandler, C.; Hack, A.; Korsakov, A.V. Aqueous fluids and hydrous melts in high-pressure and ultra-high pressure rocks: Implications for element transfer in subduction zones. Lithos 2006, 92, 399-417. [CrossRef]

22. Hermann, J.; Spandler, C.J. Sediment melts at sub-arc depths: An experimental study. J. Petrol. 2007, 49, 717-740. [CrossRef]

23. Sekine, T.; Wyllie, P.J. Experimental simulation of mantle hybridization in subduction zones. J. Geol. 1983, 91, 511-528. [CrossRef]

24. Wyllie, P.J.; Sekine, T. The formation of mantle phlogopite in subduction zone hybridization. Contrib. Mineral. Petrol. 1982, 79, 375-380. [CrossRef]

25. Plank, T.; Langmuir, C.H. The chemical composition of subducting sediment and its consequences for the crust and mantle. Chem. Geol. 1998, 145, 325-394. [CrossRef]

26. Tommasini, S.; Avanzinelli, R.; Conticelli, S. The Th/La and Sm/La conundrum of the Tethyan realm lamproites. Earth Planet. Sci. Lett. 2011, 301, 469-478. [CrossRef]

27. Avanzinelli, R.; Elliott, T.; Tommasini, S.; Conticelli, S. Constraints on the genesis of potassium-rich Italian volcanic rocks from U/Th disequilibrium. J. Petrol. 2007, 49, 195-223. [CrossRef]

28. Prelević, D.; Jacob, D.E.; Foley, S.F. Recycling plus: A new recipe for the formation of Alpine-Himalayan orogenic mantle lithosphere. Earth Planet. Sci. Lett. 2013, 362, 187-197. [CrossRef]

29. Prelević, D.; Akal, C.; Romer, R.L.; Foley, S.F. Lamproites as indicators of accretion and/or shallow subduction in the assembly of south-western Anatolia, Turkey. Terra Nova 2010, 22, 443-452. [CrossRef]

30. Wang, Y.; Foley, S.F. Hybridization Melting between Continent-derived Sediment and Depleted Peridotite in Subduction Zones. J. Geophys. Res. Solid Earth 2018, 123, 3414-3429. [CrossRef]

31. Wang, Y.; Foley, S.F.; Prelević, D. Potassium-rich magmatism from a phlogopite-free source. Geology 2017, 45, 467-470. [CrossRef]

32. Lundstrom, C.C. An experimental investigation of the diffusive infiltration of alkalis into partially molten peridotite: Implications for mantle melting processes. Geochem. Geophys. Geosyst. 2003, 4. [CrossRef]

33. Vigouroux, N.; Wallace, P.J.; Kent, A., Jr. Volatiles in high-K magmas from the western Trans-Mexican Volcanic Belt: Evidence for fluid fluxing and extreme enrichment of the mantle wedge by subduction processes. J. Petrol. 2008, 49, 1589-1618. [CrossRef]

34. Gülmez, F.; Genç, Ş.C.; Prelević, D.; Tüysüz, O.; Karacik, Z.; Roden, M.F.; Billor, Z. Ultrapotassic volcanism from the waning stage of the Neotethyan subduction: A key study from the Izmir-Ankara-Erzincan Suture Belt, Central Northern Turkey. J. Petrol. 2016, 57, 561-593. [CrossRef]

35. Sekine, T.; Wyllie, P.J. Phase relationships in the system $\mathrm{KAlSiO}_{4}-\mathrm{Mg}_{2} \mathrm{SiO}_{4}-\mathrm{SiO}_{2}-\mathrm{H}_{2} \mathrm{O}$ as a model for hybridization between hydrous siliceous melts and peridotite. Contrib. Mineral. Petrol. 1982, 79, 368-374. [CrossRef] 
36. Massonne, H.-J. Evidence for low-temperature ultrapotassic siliceous fluids in subduction zone environments from experiments in the system $\mathrm{K}_{2} \mathrm{O} \mathrm{MgO} \mathrm{Al}{ }_{2} \mathrm{O}_{3} \mathrm{SiO}_{2} \mathrm{H}_{2} \mathrm{O}$ (KMASH). Lithos 1992, 28, 421-434. [CrossRef]

37. Funk, S.P.; Luth, R.W. Melting phase relations of a mica-clinopyroxenite from the Milk River area, southern Alberta, Canada. Contrib. Mineral. Petrol. 2013, 166, 393-409. [CrossRef]

38. Lloyd, F.E.; Arima, M.; Edgar, A.D. Partial melting of a phlogopite-clinopyroxenite nodule from south-west Uganda: An experimental study bearing on the origin of highly potassic continental rift volcanics. Contrib. Mineral. Petrol. 1985, 91, 321-329. [CrossRef]

39. Bryant, J.A.; Yogodzinski, G.M.; Churikova, T.G. Melt-mantle interactions beneath the Kamchatka arc: Evidence from ultramafic xenoliths from Shiveluch volcano. Geochem. Geophys. Geosyst. 2007, 8. [CrossRef]

40. Kargin, A.V.; Sazonova, L.V.; Nosova, A.A.; Lebedeva, N.M.; Tretyachenko, V.V.; Abersteiner, A. Cr-rich clinopyroxene megacrysts from the Grib kimberlite, Arkhangelsk province, Russia: Relation to clinopyroxene-phlogopite xenoliths and evidence for mantle metasomatism by kimberlite melts. Lithos 2017, 292, 34-48. [CrossRef]

41. Aulbach, S.; Sun, J.; Tappe, S.; Höfer, H.E.; Gerdes, A. Volatile-rich metasomatism in the Cratonic Mantle beneath SW Greenland: Link to Kimberlites and Mid-lithospheric discontinuities. J. Petrol. 2017, 58, 2311-2338. [CrossRef]

42. Dawson, J.B.; Smith, J.V. The MARID (mica-amphibole-rutile-ilmenite-diopside) suite of xenoliths in kimberlite. Geochim. Cosmochim. Acta 1977, 41, 309-323. [CrossRef]

43. Conticelli, S.; Guarnieri, L.; Farinelli, A.; Mattei, M.; Avanzinelli, R.; Bianchini, G.; Boari, E.; Tommasini, S.; Tiepolo, M.; Prelević, D. Trace elements and $\mathrm{Sr}-\mathrm{Nd}-\mathrm{Pb}$ isotopes of K-rich, shoshonitic, and calc-alkaline magmatism of the Western Mediterranean Region: Genesis of ultrapotassic to calc-alkaline magmatic associations in a post-collisional geodynamic setting. Lithos 2009, 107, 68-92. [CrossRef]

44. Guo, Z.; Wilson, M.; Liu, J.; Mao, Q. Post-collisional, potassic and ultrapotassic magmatism of the northern Tibetan Plateau: Constraints on characteristics of the mantle source, geodynamic setting and uplift mechanisms. J. Petrol. 2006, 47, 1177-1220. [CrossRef]

45. Sokol, K.; Prelevic, D.; Romer, R.; Bozovic, M.; van den Bogaard, P.; Stefanova, E.; Kostic, B.; Cokulov, N. Cretaceous ultrapotassic magmatism from the Sava-Vardar zone of the Balkans. Lithos 2019, 105268. [CrossRef]

46. Huong, L.; Otter, L.; Förster, M.; Hauzenberger, C.; Krenn, K.; Alard, O.; Jochum, K. Femtosecond laser ablation-ICP-mass spectrometry and CHNS elemental analyzer reveal trace element characteristics of danburite from Mexico, Tanzania, and Vietnam. Minerals 2018, 8, 234. [CrossRef]

47. Ziaja, K.; Foley, S.F.; White, R.W.; Buhre, S. Metamorphism and melting of picritic crust in the early Earth. Lithos 2014, 189, 173-184. [CrossRef]

48. Gonzalez, C.M.; Gorczyk, W.; Gerya, T.V. Decarbonation of subducting slabs: Insight from petrological-thermomechanical modeling. Gondwana Res. 2016, 36, 314-332. [CrossRef]

49. Jochum, K.P.; Weis, U.; Stoll, B.; Kuzmin, D.; Yang, Q.; Raczek, I.; Jacob, D.E.; Stracke, A.; Birbaum, K.; Frick, D.A. Determination of reference values for NIST SRM 610-617 glasses following ISO guidelines. Geostandards Geoanalytical Res. 2011, 35, 397-429. [CrossRef]

50. Jochum, K.P.; Nohl, U.; Herwig, K.; Lammel, E.; Stoll, B.; Hofmann, A.W. GeoReM: A new geochemical database for reference materials and isotopic standards. Geostandards Geoanalytical Res. 2005, 29, 333-338. [CrossRef]

51. Griffin, W.L. GLITTER: Data reduction software for laser ablation ICP-MS. In Laser Ablation ICP-MS in the Earth Sciences: Current Practices and Outstanding Issues; Mineralogical Association of Canada: Quebec City, QC, Canada, 2008; pp. 308-311.

52. Chiodini, G.; Marini, L. Hydrothermal gas equilibria: The $\mathrm{H}_{2} \mathrm{O}-\mathrm{H}_{2}-\mathrm{CO}_{2}-\mathrm{CO}-\mathrm{CH}_{4}$ system. Geochim. Cosmochim. Acta 1998, 62, 2673-2687. [CrossRef]

53. Förster, M.W.; Prelević, D.; Buhre, S.; Mertz-Kraus, R.; Foley, S.F. An experimental study of the role of partial melts of sediments versus mantle melts in the sources of potassic magmatism. J. Asian Earth Sci. 2019, 177, 76-88. [CrossRef]

54. Falloon, T.J.; Green, D.H.; O’Neill, H.S.C.; Hibberson, W.O. Experimental tests of low degree peridotite partial melt compositions: Implications for the nature of anhydrous near-solidus peridotite melts at $1 \mathrm{GPa}$. Earth Planet. Sci. Lett. 1997, 152, 149-162. [CrossRef] 
55. Pirard, C.; Hermann, J. Experimentally determined stability of alkali amphibole in metasomatised dunite at sub-arc pressures. Contrib. Mineral. Petrol. 2005, 169, 1. [CrossRef]

56. Prelević, D.; Akal, C.; Foley, S.F.; Romer, R.L.; Stracke, A.; van den Bogaard, P. Ultrapotassic mafic rocks as geochemical proxies for post-collisional dynamics of orogenic lithospheric mantle: The case of southwestern Anatolia, Turkey. J. Petrol. 2012, 53, 1019-1055. [CrossRef]

57. Liu, D.; Zhao, Z.; Zhu, D.-C.; Niu, Y.; DePaolo, D.J.; Harrison, T.M.; Mo, X.; Dong, G.; Zhou, S.; Sun, C. Postcollisional potassic and ultrapotassic rocks in southern Tibet: Mantle and crustal origins in response to India-Asia collision and convergence. Geochim. Cosmochim. Acta 2014, 143, 207-231. [CrossRef]

58. Martin, A.M.; Médard, E.; Righter, K.; Lanzirotti, A. Intraplate mantle oxidation by volatile-rich silicic magmas. Lithos 2017, 292, 320-333. [CrossRef]

59. Mattsson, H.B.; Nandedkar, R.H.; Ulmer, P. Petrogenesis of the melilititic and nephelinitic rock suites in the Lake Natron-Engaruka monogenetic volcanic field, northern Tanzania. Lithos 2013, 179, 175-192. [CrossRef]

60. Förster, M.W.; Prelević, D.; Schmück, H.R.; Buhre, S.; Marschall, H.R.; Mertz-Kraus, R.; Jacob, D.E. Melting phlogopite-rich MARID: Lamproites and the role of alkalis in olivine-liquid Ni-partitioning. Chem. Geol. 2018, 476, 429-440. [CrossRef]

61. Sekine, T.; Wyllie, P.J. The system granite-peridotite- $\mathrm{H}_{2} \mathrm{O}$ at $30 \mathrm{kbar}$, with applications to hybridization in subduction zone magmatism. Contrib. Mineral. Petrol. 1982, 81, 190-202. [CrossRef]

62. Ersoy, E.Y.; Helvac1, C.; Palmer, M.R. Mantle source characteristics and melting models for the early-middle Miocene mafic volcanism in Western Anatolia: Implications for enrichment processes of mantle lithosphere and origin of K-rich volcanism in post-collisional settings. J. Volcanol. Geotherm. Res. 2010, 198, 112-128. [CrossRef]

63. Stepanov, A.S.; Hermann, J.; Rubatto, D.; Korsakov, A.V.; Danyushevsky, L.V. Melting history of an ultrahigh-pressure paragneiss revealed by multiphase solid inclusions in garnet, Kokchetav massif, Kazakhstan. J. Petrol. 2016, 57, 1531-1554. [CrossRef]

64. Mallik, A.; Nelson, J.; Dasgupta, R. Partial melting of fertile peridotite fluxed by hydrous rhyolitic melt at 2-3 GPa: Implications for mantle wedge hybridization by sediment melt and generation of ultrapotassic magmas in convergent margins. Contrib. Mineral. Petrol. 2015, 169, 48. [CrossRef]

65. Foley, S.F. Experimental constraints on phlogopite chemistry in lamproites: 1 . The effect of water activity and oxygen fugacity. Eur. J. Mineral. 1989, 1, 411-426. [CrossRef]

66. Shaw, D.M. Trace element fractionation during anatexis. Geochim. Cosmochim. Acta 1970, 34, $237-243$. [CrossRef]

67. Sun, S.-S.; McDonough, W.-S. Chemical and isotopic systematics of oceanic basalts: Implications for mantle composition and processes. Geol. Soc. Lond. Spec. Publ. 1989, 42, 313-345. [CrossRef]

68. Borghini, A.; Ferrero, S.; Wunder, B.; Laurent, O.; O’Brien, P.J.; Ziemann, M.A. Granitoid melt inclusions in orogenic peridotite and the origin of garnet clinopyroxenite. Geology 2018, 46, 1007-1010. [CrossRef]

69. Peccerillo, A. The Roman Province. Cenozoic Volcanism in the Tyrrhenian Sea Region; Springer: Berlin/Heidelberg, Germany, 2017; pp. 81-124.

70. Murphy, D.T.; Collerson, K.D.; Kamber, B.S. Lamproites from Gaussberg, Antarctica: Possible transition zone melts of Archaean subducted sediments. J. Petrol. 2002, 43, 981-1001. [CrossRef]

71. Foley, S.F.; Jenner, G.A. Trace element partitioning in lamproitic magmas-The Gaussberg olivine leucitite. Lithos 2004, 75, 19-38. [CrossRef]

72. Nelson, D.R. Isotopic characteristics of potassic rocks: Evidence for the involvement of subducted sediments in magma genesis. Lithos 1992, 28, 403-420. [CrossRef]

73. Jaques, A.L.; Foley, S.F. Insights into the petrogenesis of the West Kimberley lamproites from trace elements in olivine. Mineral. Petrol. 2018. [CrossRef]

(C) 2019 by the authors. Licensee MDPI, Basel, Switzerland. This article is an open access article distributed under the terms and conditions of the Creative Commons Attribution (CC BY) license (http://creativecommons.org/licenses/by/4.0/). 